\title{
Digital Undergraduate Education in Dentistry: A Systematic Review
}

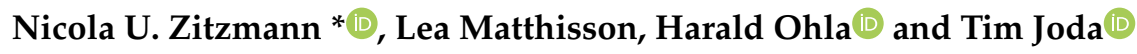 \\ Department of Reconstructive Dentistry, University Center for Dental Medicine Basel, University of Basel, \\ 4058 Basel, Switzerland; lea.matthisson@unibas.ch (L.M.); h.ohla@unibas.ch (H.O.); tim.joda@unibas.ch (T.J.) \\ * Correspondence: n.zitzmann@unibas.ch; Tel.: +41-61-267-2636
}

Received: 23 March 2020; Accepted: 2 May 2020; Published: 7 May 2020

\begin{abstract}
The aim of this systematic review was to investigate current penetration and educational quality enhancements from digitalization in the dental curriculum. Using a modified PICO strategy, the literature was searched using PubMed supplemented with a manual search to identify English-language articles published between 1994 and 2020 that reported the use of digital techniques in dental education. A total of 211 articles were identified by electronic search, of which 55 articles were selected for inclusion and supplemented with 27 additional publications retrieved by manual search, resulting in 82 studies that were included in the review. Publications were categorized into five areas of digital dental education: Web-based knowledge transfer and e-learning, digital surface mapping, dental simulator motor skills (including intraoral optical scanning), digital radiography, and surveys related to the penetration and acceptance of digital education. This review demonstrates that digitalization offers great potential to revolutionize dental education to help prepare future dentists for their daily practice. More interactive and intuitive e-learning possibilities will arise to stimulate an enjoyable and meaningful educational experience with 24/7 facilities. Augmented and virtual reality technology will likely play a dominant role in the future of dental education.
\end{abstract}

Keywords: dental education; digital dentistry; augmented reality (AR); virtual reality (VR)

\section{Introduction}

The implementation of digital technologies in dental curricula has started globally and reached varying levels of penetration depending on local resources and demands. One of the biggest challenges in digital education is the need to continuously adapt and adjust to the developments in technology and apply these to dental practice [1]. Most dental offices in Europe are equipped with software solutions for managing patients' records, agenda and recall reminders; recording provided services, including working time schedules; ordering materials; and managing the maintenance contracts of medical devices. These systems incorporate medical histories, digital radiographs, intraoral photographs, medicine lists, and correspondences. The systems also enable easy access to detailed odontograms showing fillings per tooth surface, restorations and carious lesions, periodontal status with visualization of the attachment level, probing pocket depth, and recession [2].

The introduction of intraoral optical scanning (IOS) allows the current anatomic situation to be digitized, enabling chairside or laboratory fabrication of restorations, to plan oral rehabilitations with a set-up [3], and/or to superimpose the situation with 3-dimensional (3D) radiography (e.g., for guided implant placement) [4]. While the penetration of these scanners in dental offices is still limited (present in an estimated 20\%-25\% of European dental offices) [5], laboratory scanners are presumably used by more than two-thirds of dental laboratories. The dental technician uses the 3D model files derived from IOS by the clinician or from scanned conventional casts to facilitate the fabrication of restorations. Compared to waxing, the digital design offers several advantages for quality control, 
such as providing data about material thickness and values of connector cross sections. While the main shortcomings of lost wax casting were erroneous castings or shrinkage cavities, with a digital workflow the laboratory benefits from improved material properties when industrially manufactured products can be used with subtractive milling or additive printing processes [6].

3D education programs have been introduced to enhance students' spatial ability, their interactivity, critical thinking, and clinical correlations with the integration of multiple dental disciplines. Augmented reality in 3D visualization allows insights in tooth morphology, and also facilitates treatment planning with fixed or removable partial denture (RPD) programs [7]. Digital technologies also include the 3D printing of virtual teeth, which has been suggested to enhance transparency for all students due to the identical setups [8].

A recent review on the application of augmented reality (AR) and virtual reality (VR) in dental medicine demonstrated that the use of AR/VR technologies for educational motor skill training and clinical testing of maxillofacial surgical protocols is increasing [9]. It was concluded that these digital technologies are valuable in dental undergraduate and postgraduate education, offering interactive learning concepts with $24 / 7$ access and objective evaluation. A recent scoping review analyzed the application of VR in pre-clinical dental education and identified four educational thematic areas (simulation hardware, realism of simulation, scoring systems, and validation), highlighting the need for a better evidence base for the utility of VR in dental education [10]. In communicating with dental professionals, medical doctors, dental technicians, and insurance providers, dental students have to be prepared to manage digitized data, ensure patient safety, and understand the benefits and limitations of conventional and digital processes.

Overall, digitalization seems to have had a major impact on dental education, addressing various aspects, such as e-learning and Web-based knowledge transfer, but also related to diagnostics using 3D imaging and digital radiography, and practically oriented trainings in terms of dental simulator motor skills including IOS with 3D printing, prototyping, and digital surface mapping. Digital applications can provide additional opportunities to evaluate and improve education, implementing evidence-based surveys related to the penetration and acceptance of digital education.

The aim of this systematic review was: (i) to investigate the current level of implementation of digital technology in dental education; and (ii) to outline the educational quality enhancements that result from digitalization in main focus areas within the dental curriculum.

\section{Materials and Methods}

This systematic review was conducted in accordance with the guidelines of Preferred Reporting Items of Systematic Reviews and Meta-Analyses (PRISMA) [11]. A systematic electronic search of PubMed was performed, limited to English-language articles published between 1 January 1994 and 15 April 2020. A modified PICO search was defined for Population/TOPIC, Intervention/METHOD, and Outcome/INTEREST; whereas Comparison was omitted. The search syntax used was: ((students[MeSH]) AND (education, dental[MeSH] OR teaching[MeSH] AND digital)) AND (dentistry[MeSH] OR dental medicine). In addition, the bibliographies of all full texts selected from the electronic search were manually searched, and an extensive search of articles published in the Journal of Dental Education and the European Journal of Dental Education was conducted.

This systematic review focused on randomized controlled trials, cohort studies, case-control studies, observational trials, and descriptive studies that investigated the application of digital technologies in dental education. Reports without an underlying study design and studies not involving dental students were not included. Furthermore, the vast body of literature about the transition from glass to digital slide microscopy was also excluded. Four reviewers (N.U.Z., T.J., L.M., H.O.) independently screened the titles, abstracts, and the full texts of the identified articles to select those for inclusion in the review. Disagreements were resolved by discussion. Duplicates or preliminary reports that were followed by original publications were excluded. 


\section{Results}

A total of 211 titles were identified by the electronic search (Figure 1). After screening of the titles, abstracts, and full-text articles, 55 publications were included that reported a digital application in dental education. The manual search retrieved 27 additional publications, resulting in the inclusion of 82 studies (Annex S1 and Annex S2).

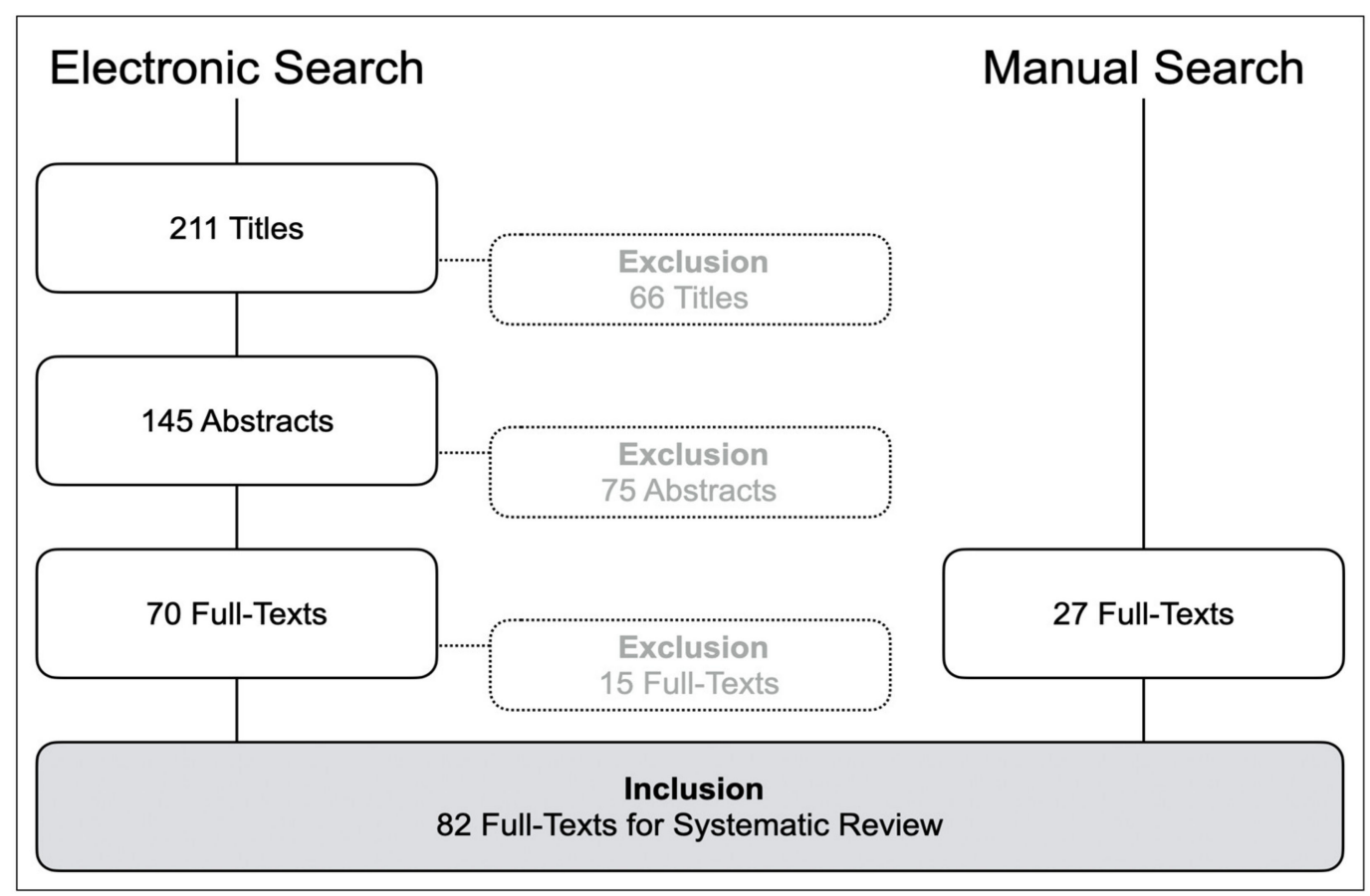

Figure 1. Systematic search strategy.

The publications were categorized into six areas of digital dental education:

- Web-based knowledge transfer/e-learning (22 studies);

- Digital surface mapping (20 studies);

- Dental simulator motor skills including IOS (23 studies);

- 3D printing and prototyping (2 studies);

- Digital radiography (5 studies); and

- Surveys related to the penetration and acceptance of digital education (10 studies).

\subsection{Web-Based Knowledge Transfer/e-Learning}

Fifteen studies reported the use of Web-based learning tools in the dental curriculum, comprising orthodontics [12,13], tooth anatomy [14-16], oral pathogens and immunology [17], dental radiology [18,19], oral surgery [20] or implant dentistry [21], prosthetic dentistry [22], caries detection [23,24], in growth and development [25], and the general use of Web-based learning tools [26] (Table 1). Three additional studies reported on the use of video illustrations of clinical procedures with behavior management in pediatric dentistry [27], intraoral suturing [28], or tooth preparation [29]. Practicing history-taking and decision-making in periodontology with a Web-based database application, where students used free text communication on the screen to interact with patient data, improved their capability and empathy during the first patient contact [30]. One other study described the introduction of portable digital assistants for undergraduate students in a primary dental care clinic to access a virtual learning environment; these tools proved to be a convenient and versatile method for accessing online education [31]. Mobile devices were found to support learning by offering the opportunity to personalize digital learning materials by making comments, underlining, annotating images, 
and making drawings [32]. The availability of free 3D viewer software favored the planning of RPD designs on 3D virtual model situations [33]. Online access to digital tools without time restrictions was identified as a major benefit in dental education, and Web-based instructional modules facilitated students' individual learning approach and accommodated varying learning paces. While an initial effort was required to prepare online educational material, faculty time was reduced in the long term.

Table 1. Web-based knowledge transfer / e-learning $(n=22)$.

\begin{tabular}{|c|c|c|c|c|c|}
\hline Study (Year) & Study Design & Theory/Practice & Participants & Materials and Methods & Results \\
\hline $\begin{array}{c}\text { Komolpis et al. } \\
2002[12]\end{array}$ & $\mathrm{RCT}$ & $\mathrm{P}$ & 99 & $\begin{array}{l}\text { Compared effectiveness (exam scores and } \\
\text { time spent) in clinical orthodontic diagnosis } \\
\text { in test group ( } 50 \text { students with web-based } \\
\text { digital records) and control group ( } 49 \\
\text { students provided with traditional records) } \\
\text { with study models, panoramic and } \\
\text { cephalometric radiograph, facial and } \\
\text { intraoral photographs. }\end{array}$ & $\begin{array}{l}\text { Test and control group } \\
\text { performed similar in the exam } \\
\text { with no difference in test time; } \\
\text { positive feedback about the } \\
\text { web-based learning module, } \\
\text { students benefit from } \\
\text { convenient access to study } \\
\text { material on the computer } \\
\text { without time constrictions. }\end{array}$ \\
\hline $\begin{array}{l}\text { Schultze-Mosgau } \\
\text { et al. } 2004 \text { [20] }\end{array}$ & OT & $\mathrm{T}$ & 82 & $\begin{array}{l}\text { Evaluated a web-based course with a } \\
\text { concluding online examination. Feed-back } \\
\text { by questionnaire. }\end{array}$ & $\begin{array}{l}\text { Course gradings excellent or } \\
\text { good were given for } \\
\text { accessibility independent of } \\
\text { time }(89 \%) \text {, for access } \\
\text { independent of location }(83 \%) \text {, } \\
\text { for objectification of } \\
\text { knowledge transfer }(67 \%) \text {, and } \\
\text { for use of videos for surgical } \\
\text { techniques ( }(91 \%) .\end{array}$ \\
\hline $\begin{array}{l}\text { Schittek Janda } \\
\text { et al. } 2004 \text { [30] }\end{array}$ & RCT & $P$ & 39 & $\begin{array}{l}\text { Compared the effect of a web-based virtual } \\
\text { learning environment (VLE) on students' } \\
\text { performance in history interview. Both } \\
\text { groups underwent standard instruction in } \\
\text { professional behavior, history taking, clinical } \\
\text { decision making and treatment planning. } \\
\text { Test group worked with the virtual } \\
\text { periodontal patient for } 1 \text { week prior to their } \\
\text { first patient contact; control group was first } \\
\text { allowed to use the virtual patient after their } \\
\text { first patient contact. Time spent, type and } \\
\text { order of questions and professional behavior } \\
\text { were analyzed. }\end{array}$ & $\begin{array}{l}\text { Test group asked more } \\
\text { relevant questions, spent more } \\
\text { time on patient issues, and } \\
\text { performed a more complete } \\
\text { history interview than control. } \\
\text { The use of the virtual patient } \\
\text { and the process of writing } \\
\text { questions in working with the } \\
\text { virtual patient stimulated } \\
\text { students to organize their } \\
\text { knowledge and resulted in } \\
\text { more confident behavior } \\
\text { towards the patient. }\end{array}$ \\
\hline $\begin{array}{l}\text { Boynton et al. } \\
2006[27]\end{array}$ & CS & $P$ & 108 & $\begin{array}{l}\text { Explored students' behaviors management in } \\
\text { pediatric dentistry using portable video } \\
\text { instructions; test group: } 11 \text { students } \\
\text { reviewing video lecture material on a } \\
\text { portable device (iPod) supplementing } \\
\text { conventional pediatric behavior management } \\
\text { lecture; additional } 6 \text { students (intermediate) } \\
\text { used audio versions or video on the } \\
\text { computer; control group: } 91 \text { students } \\
\text { without digital learning material; exam on } \\
\text { student comprehension. }\end{array}$ & $\begin{array}{l}\text { Test group performed } \\
\text { significantly better on the } \\
\text { examination (mean 9.3) than } \\
\text { control ( } 7.9 \text { ) or intermediate } \\
\text { group (7.8); portable format } \\
\text { was preferred. }\end{array}$ \\
\hline $\begin{array}{l}\text { Reynolds et al. } \\
2007 \text { [31] }\end{array}$ & CS & $\mathrm{P}$ & 12 & $\begin{array}{l}\text { Investigated students' educational use of } \\
\text { portable digital assistants (PDA) to access a } \\
\text { Virtual Learning Environment in a primary } \\
\text { dentalcare clinic and at home; cross over trial } \\
\text { with } 6 \text { students with / } 6 \text { without for } 12 \text { weeks. }\end{array}$ & $\begin{array}{l}\text { PDA was frequently used for } \\
\text { online education; over } 90 \% \\
\text { wanted PDA as part of their } \\
\text { dental kit. }\end{array}$ \\
\hline $\begin{array}{c}\text { Kingsley et al. } \\
2009 \text { [17] }\end{array}$ & CS & $\mathrm{P}$ & 78 & $\begin{array}{l}\text { Examined students' ability to use web-based } \\
\text { online technologies to find recently } \\
\text { published online citations and to answer } \\
\text { clinically relevant questions (oral pathogens } \\
\text { and immunology course); technology skills } \\
\text { analyzed: ability to locate online library } \\
\text { resources, understand how information is } \\
\text { organized within the library system, access } \\
\text { online databases, interpret and evaluate } \\
\text { research materials within the context of a } \\
\text { specific discipline; students were provided } \\
\text { with a review article of vaccines against } \\
\text { caries from } 2001 \text {. }\end{array}$ & $\begin{array}{l}100 \% \text { of students had correct } \\
\text { responses to the } \\
\text { content-specific or } \\
\text { technology-independent } \\
\text { portions; } 46 \% \text { had correct } \\
\text { responses to the information } \\
\text { literacy or } \\
\text { technology-dependent } \\
\text { portions; as web-based } \\
\text { technologies grow more } \\
\text { prevalent in the digital era, } \\
\text { information literacy and } \\
\text { technology-dependent, } \\
\text { applied research assignments } \\
\text { should be integrated into } \\
\text { graduate-level curricula. }\end{array}$ \\
\hline $\begin{array}{c}\text { Weaver et al. } \\
2009 \text { [28] }\end{array}$ & $\mathrm{RCT}$ & $P$ & 12 & $\begin{array}{l}\text { Evaluated performance in intraoral suturing } \\
\text { after digital multimedia instruction; control } \\
\text { group: written information; test group: plus } \\
\text { teaching tool; suturing performed on a model } \\
\text { situation, evaluated by } 10 \text { grading criteria. }\end{array}$ & $\begin{array}{l}\text { Test group performed better } \\
\text { than control; video addressed } \\
\text { common mistakes made by } \\
\text { novice students, improved } \\
\text { long-term understanding of } \\
\text { the basic suture principles. }\end{array}$ \\
\hline
\end{tabular}


Table 1. Cont.

\begin{tabular}{|c|c|c|c|c|c|}
\hline Study (Year) & Study Design & Theory/Practice & Participants & Materials and Methods & Results \\
\hline $\begin{array}{l}\text { Wright et al. } \\
2009 \text { [14] }\end{array}$ & OT & $\mathrm{T}$ & 235 & $\begin{array}{l}\text { Determined whether dental students used an } \\
\text { interactive DVD-tooth atlas as a study aid } \\
\text { and perceived the 3D interactive tooth atlas } \\
\text { as a value-added learning experience. }\end{array}$ & $\begin{array}{l}14 \% \text { students downloaded the } \\
\text { DVD voluntarily prior to } \\
\text { adding atlas-related exam } \\
\text { questions as incentives; after } \\
\text { adding incentives } 43 \% \\
\text { downloaded the material; } \\
\text { financial concerns and overly } \\
\text { sophisticated content were } \\
\text { deemed responsible for the } \\
\text { low acceptance. }\end{array}$ \\
\hline $\begin{array}{c}\text { Curnier } 2010 \\
{[16]}\end{array}$ & OT & $\mathrm{P}$ & 26 & $\begin{array}{l}\text { Assessed VR integration into teaching of } \\
\text { dental anatomy, feedback by questionnaire }\end{array}$ & $\begin{array}{l}70 \% \text { of the students were } \\
\text { satisfied/very satisfied with IT } \\
\text { integration in the curriculum. }\end{array}$ \\
\hline $\begin{array}{l}\text { Bains et al. } \\
2010[13]\end{array}$ & $\mathrm{RCT}$ & $\mathrm{T}$ & 90 & $\begin{array}{l}\text { Compared effectiveness and attitudes toward } \\
\text { e-learning (EL, online tutorial without } \\
\text { teacher), face-to-face learning (F2FL, led by } \\
\text { teacher) and blended learning (BL) } \\
\text { subdivided in BL1 (EL first then F2FL) and } \\
\text { BL2 (F2FL first then EL) among 4th year } \\
\text { students. Groups received cephalometric } \\
\text { tutorial in the allocated mode, answered an } \\
\text { MCQ (Multiple Choice Questionnaire). }\end{array}$ & $\begin{array}{l}\text { F2FL and BL resulted in } \\
\text { similar test results; EL alone } \\
\text { was less effective. BL was the } \\
\text { most and F2FL was the least } \\
\text { accepted method, EL was } \\
\text { significantly less preferred, the } \\
\text { order B1 or } 2 \text { had no effect. }\end{array}$ \\
\hline $\begin{array}{l}\text { Mitov et al. } \\
2010[15]\end{array}$ & CS & $\mathrm{T}$ & 36 & $\begin{array}{l}\text { Testing an e-learning software (morphoDent) } \\
\text { to prepare for an anatomy exam. 3D models } \\
\text { with description and x-rays of permanent } \\
\text { human teeth were available for viewing and } \\
\text { interaction on the learning platform. Practical } \\
\text { dental morphology exam was compared to } \\
\text { virtual tooth anatomy exam. Evaluation of } \\
\text { students' perceptions in a questionnaire. }\end{array}$ & $\begin{array}{l}\text { Similar exam scores in } \\
\text { traditional and online exam. } \\
\text { Majority felt the software } \\
\text { helped them learning dental } \\
\text { morphology, despite of } \\
\text { difficulties in operating } \\
\text { the program. }\end{array}$ \\
\hline $\begin{array}{l}\text { Vuchkova et al. } \\
2012[19]\end{array}$ & CS & $\mathrm{P}$ & 88 & $\begin{array}{l}\text { Evaluated interactive digital versus } \\
\text { conventional radiology textbook (course } \\
\text { radiographic anatomy), outcome was } \\
\text { radiographic interpretation test and } \\
\text { survey feedback. }\end{array}$ & $\begin{array}{l}95 \% \text { perceived positive } \\
\text { enhancement of learning and } \\
\text { interpretation. }\end{array}$ \\
\hline $\begin{array}{l}\text { Qi et al. } 2013 \\
\text { [21] }\end{array}$ & $\mathrm{RCT}$ & $\mathrm{P}$ & 95 & $\begin{array}{l}\text { Comparison of active versus passive } \\
\text { approaches in using 3D virtual scenes in } \\
\text { dental implant cases. Students were exposed } \\
\text { to educational materials about implant } \\
\text { restoration on three types of webpages: } \\
\text { traditional 2D (group 1); active-controlling } \\
\text { 3D (group 2); passive-controlling 3D (group } \\
\text { 3). After reviewing their webpages, students } \\
\text { were asked to complete a posttest to assess } \\
\text { the relative quality of information acquisition. } \\
\text { Before study exposure, students performed a } \\
\text { standardized test of spatial ability (mental } \\
\text { rotations test, MRT). }\end{array}$ & $\begin{array}{l}\text { Posttest scores were highest in } \\
\text { group } 3 \text { (passive control) and } \\
\text { lowest in group } 2 \text { (active } \\
\text { control). Higher MRT scores } \\
\text { were associated with better } \\
\text { posttest performances in all } \\
\text { three groups. Individuals with } \\
\text { low spatial ability did not } \\
\text { benefit from 3D interactive } \\
\text { virtual reality, while passive } \\
\text { control produced higher } \\
\text { learning effects compared to } \\
\text { active control. }\end{array}$ \\
\hline $\begin{array}{l}\text { Reissmann et al. } \\
\text { 2015 [22] }\end{array}$ & OT & $\mathrm{T}$ & 71 & $\begin{array}{l}\text { Creation of a blended learning model; } \\
\text { e-learning modules covered fundamental } \\
\text { principles, additional information, and } \\
\text { learning tests (tests were repeated until } \\
\text { passed and the next video sequence } \\
\text { unlocked); modules comprised (i) tooth } \\
\text { preparation, placement of post and core, and } \\
\text { provisional crown; (ii) with preparation, } \\
\text { manufacturing and insertion of a FDP (Fixed } \\
\text { Dental Prosthesis). Students rated the course } \\
\text { on a questionnaire, comparison to previous } \\
\text { courses without e-learning. }\end{array}$ & $\begin{array}{l}\text { Significantly higher } \\
\text { satisfaction among students } \\
\text { enrolled in the e-learning } \\
\text { modules compared to the } \\
\text { years prior to integration of } \\
\text { the e-learning tests. Results } \\
\text { suggest that instructor-based } \\
\text { practical demonstrations in } \\
\text { preclinical courses in } \\
\text { prosthetic dentistry could be } \\
\text { successfully replaced by } \\
\text { e-learning applications } \\
\text { provided that course content } \\
\text { is structured according to } \\
\text { specific predefined learning } \\
\text { goals and procedures. }\end{array}$ \\
\hline
\end{tabular}


Table 1. Cont.

\begin{tabular}{|c|c|c|c|c|c|}
\hline Study (Year) & Study Design & Theory/Practice & Participants & Materials and Methods & Results \\
\hline $\begin{array}{c}\text { Gonzales et al. } \\
2016 \text { [18] }\end{array}$ & OT & $\mathrm{T}$ & 40 & $\begin{array}{c}\text { Implementation social media (Twitter) in a } \\
\text { dental radiology course and evaluated } \\
\text { students' use and perception by a } \\
\text { questionnaire. }\end{array}$ & $\begin{array}{l}95 \%(38) \text { had not used Twitter } \\
\text { prior to the course; } 53 \%(21) \\
\text { created an account during the } \\
\text { course to view radiographic } \\
\text { examples and stay informed; } \\
\text { overall Twitter had a positive } \\
\text { impact with improved } \\
\text { accessibility to the instructor. }\end{array}$ \\
\hline $\begin{array}{c}\text { Jackson et al. } \\
2018 \text { [25] }\end{array}$ & OT & $\mathrm{P}$ & 80 & $\begin{array}{l}\text { Evaluated dental students study patterns } \\
\text { using self-directed web-based learning } \\
\text { modules with scheduled self-study time } \\
\text { instead of lectures; web-based module access } \\
\text { (date and time) was recorded for four courses } \\
\text { in the growth \& development curriculum; } \\
\text { scheduled access time was } 8 \text { am to } 5 \mathrm{pm} \text {. }\end{array}$ & $\begin{array}{l}\text { Frequency of module access (at } \\
\text { least once) varied among the } \\
\text { four courses (10-64\%); only } \\
\text { three students had }>20 \% \text { of } \\
\text { their total accesses taking place } \\
\text { during designated self-study } \\
\text { times. For all courses the } \\
\text { proportion of module access } \\
\text { was significantly higher } 0-2 \\
\text { days before an exam compared } \\
\text { to } 3-7 \text { or }>7 \text { days before final } \\
\text { exam; no association between } \\
\text { module access during scheduled } \\
\text { times and course performance. }\end{array}$ \\
\hline $\begin{array}{l}\text { Alves et al. } \\
2018 \text { [23] }\end{array}$ & RCT & $\mathrm{P}$ & 64 & $\begin{array}{l}\text { Evaluated the effect of a digital learning tool } \\
\text { on students' caries detection in } 80 \text { teeth using } \\
\text { ICDAS; Group } 1 \text { ( } 21 \text { students): ICDAS } \\
\text { e-learning program; group } 2 \text { ( } 22 \text { students): } \\
\text { plus digital learning tool; group } 3 \text { ( } 21 \\
\text { students): no training; reassessment of the } 80 \\
\text { teeth } 2 \text { weeks after training. }\end{array}$ & $\begin{array}{l}\text { After training group } 1 \text { and } 2 \text { had } \\
\text { improved with significantly } \\
\text { higher sensitivity and } \\
\text { specificity; group } 3 \text { had } \\
\text { increased sensitivity at the D2 } \\
\text { thresholds; ICDAS e-learning } \\
\text { with or without digital learning } \\
\text { tool improved occlusal } \\
\text { caries detection. }\end{array}$ \\
\hline $\begin{array}{l}\text { Botelho et al. } \\
2019 \text { [26] }\end{array}$ & OT & $\mathrm{T}$ & 40 & $\begin{array}{c}\text { Surveyed dental students' perception of } \\
\text { cloud-based practice records (documenting } \\
\text { clinical progression) compared to traditional } \\
\text { paper record. }\end{array}$ & $\begin{array}{l}\text { Cloud based records were rated } \\
\text { significantly better in terms of } \\
\text { usefulness, ease of use, and } \\
\text { learning, satisfaction. }\end{array}$ \\
\hline $\begin{array}{c}\text { Pyörälä et al. } \\
2019 \text { [32] }\end{array}$ & OT & $\mathrm{T}$ & 176 & $\begin{array}{l}\text { Investigated perception of mobile devices for } \\
\text { study use among } 124 \text { medical, } 52 \text { dental } \\
\text { students provided with iPads and followed } \\
\text { from } 1 \text { st to } 5 \text { th year; feed-back } \\
\text { by questionnaire. }\end{array}$ & $\begin{array}{l}\text { Note taking was the most } \\
\text { frequent application of the } \\
\text { mobile device in the 1st-5th } \\
\text { year; students personalized } \\
\text { digital learning materials by } \\
\text { making comments, underlining, } \\
\text { marking images and drawings. } \\
\text { Students retrieved their notes } \\
\text { anytime when studying for } \\
\text { examinations and treating } \\
\text { patients in clinical practice. }\end{array}$ \\
\hline $\begin{array}{c}\text { Mahrous et al. } \\
2019 \text { [33] }\end{array}$ & $\mathrm{RCT}$ & $\mathrm{P}$ & 77 & $\begin{array}{l}\text { Compared virtual 3D casts with 2D } \\
\text { paper-based exercise in planning removable } \\
\text { partial denture design; group } 1(n=39) \\
\text { planned RPD in Kennedy class IV in virtual } \\
\text { 3D and Kennedy class II in traditional 2D } \\
\text { format, group 2 ( }=38 \text { ) planned class IV } \\
\text { traditional and class II virtual; survey lines } \\
\text { and undercut positions were drawn on } \\
\text { virtual 3D casts or given in written } \\
\text { descriptions (2D); students planned design } \\
\text { (with rests, clasp type, retention location, } \\
\text { guide plane) was scored; feed-back } \\
\text { by questionnaire. }\end{array}$ & $\begin{array}{l}\text { Similar scores for 3D and 2D } \\
\text { exercises; majority favored } \\
\text { virtual 3D casts because of } \\
\text { improved understanding of } \\
\text { relevant parameters and spatial } \\
\text { visualization. Currently, } \\
\text { physical casts are still required } \\
\text { to practice surveying and } \\
\text { drawing on the cast. }\end{array}$ \\
\hline
\end{tabular}

RCT = Randomized Controlled Trial; CT = Controlled Trial; CS = Cohort Study; CCS = Case-Control-Study; OT = Observational Study.

\subsection{Digital Surface Mapping}

Visual inspection of students' work is known to have shortcomings in inter- and intra-examiner reliability, whereas standardized digital surface mapping of abutment tooth preparations facilitates objective evaluation and feedback (Table 2) [34-46]. In the preclinical training of dental students, the use of software that can match the student's scanned preparation with an ideal tooth preparation has been proven to be a helpful tool in the evaluation of preparation form, taper, and substance removal. High intra-rater agreement was also found for the repeated digital grading of wax-ups in the undergraduate curriculum [47], and students' initial self-assessment was overrated compared to the digital grading [48]. Limitations of digital assessments have been found for intracoronal cavity preparations, due to the restricted analysis of cavity depth $[49,50]$. With specified software skills, 
successful application was documented for class II mesio-occlusal-distal (MOD) cavity assessments, class III composite preparations, and mesio-occlusal (MO) onlay preparations [51-53]. These studies of digital surface mapping clearly demonstrate the tremendous development of this technology since 2006, which now enables a thorough and consistent analysis of several preparation parameters, with freely available open-source comparison tools.

Table 2. Digital surface mapping $(n=20)$.

\begin{tabular}{|c|c|c|c|c|c|}
\hline Study (Year) & Study Design & Theory/Practice & Participants & Materials and Methods & Results \\
\hline $\begin{array}{c}\text { Esser et al. } 2006 \\
\text { [35] }\end{array}$ & CS & $P$ & 36 & $\begin{array}{l}\text { Compared conventional visual } \\
\text { examination by faculty with digital } \\
\text { analysis (“Prep Assistant”) of students' } \\
\text { preparation of a central incisor for a } \\
\text { metal-ceramic crown; preparations } \\
\text { were scanned; before the exam } \\
\text { preparation, students had received } \\
\text { theoretical and practical exercises. }\end{array}$ & $\begin{array}{l}\text { Digital measuring technique was } \\
\text { superior for convergence angle, } \\
\text { occlusal reduction and width of } \\
\text { shoulder; low correlation between } \\
\text { visual and digital was observed } \\
\text { for the assessments of chamfer, } \\
\text { path of insertion, width of bevel } \\
\text { and basic form; calibration of } \\
\text { evaluators benefit from digital } \\
\text { analysis tool. }\end{array}$ \\
\hline $\begin{array}{l}\text { Hamil et al. } \\
2014 \text { [37] }\end{array}$ & OT & $P$ & 81 & $\begin{array}{l}\text { Evaluated dental students' opinion } \\
\text { about a new grading software program } \\
\text { (E4D Compare with surface mapping } \\
\text { technology) for their self-assessment } \\
\text { and as faculty-grading tool in a } \\
\text { preclinical course to evaluate crown } \\
\text { preparations. Software was introduced } \\
\text { (one-hour lecture and three-hour } \\
\text { hands-on laboratory session) and } \\
\text { applied for self-assessment during one } \\
\text { semester; questionnaire about } \\
\text { students' perception. }\end{array}$ & $\begin{array}{l}\text { Students preferred digital grading } \\
\text { system over traditional } \\
\text { hand-grading } 95 \% \text { reported on } \\
\text { feedback inconsistencies among } \\
\text { different faculty members, } 72 \% \\
\text { reported on inconsistencies from } \\
\text { the examiner; } 85 \% \text { agreed or } \\
\text { strongly agreed that E4D } \\
\text { Compare provided more } \\
\text { consistent grading than faculty; } \\
79 \% \text { responded that the software } \\
\text { provided more feedback, } 90 \% \\
\text { found the software helping them } \\
\text { to understand their deficiencies; } \\
89 \% \text { agreed or strongly agreed } \\
\text { that E4D Compare grading helped } \\
\text { them be better clinicians. }\end{array}$ \\
\hline $\begin{array}{l}\text { Mays et al. } \\
2014 \text { [49] }\end{array}$ & $\mathrm{CT}$ & $\mathrm{P}$ & 25 & $\begin{array}{c}\text { Compared students' visual } \\
\text { self-assessment, students' digital } \\
\text { (CAD/CAM) self-assessment, faculty } \\
\text { visual assessment, and faculty digital } \\
\text { assessment. Students prepared } \\
\text { mesial-occlusal amalgam cavity, used } \\
\text { standardized grading sheets for visual } \\
\text { self-assessment, scanned their } \\
\text { preparation, used design tool of Cerec } \\
\text { software for digital self-assessment. }\end{array}$ & $\begin{array}{l}\text { Moderate agreement between } \\
\text { faculty visual and digital } \\
\text { evaluation for occlusal and } \\
\text { proximal shape, orientation and } \\
\text { definition; poor agreement } \\
\text { between student visual and } \\
\text { digital evaluation for occlusal } \\
\text { shape, and fair for proximal } \\
\text { shape, orientation and definition; } \\
\text { slight to poor agreement between } \\
\text { students visual and faculty visual } \\
\text { evaluation, and digital assessment } \\
\text { did not improve } \\
\text { student/faculty agreement. }\end{array}$ \\
\hline $\begin{array}{l}\text { Kwon et al. } \\
2014 \text { [47] }\end{array}$ & OT & $\mathrm{P}$ & 60 & $\begin{array}{l}\text { Compared conventional visual faculty } \\
\text { grading of wax-ups to digital } \\
\text { assessment in dental anatomy course; } \\
30 \text { faculty wax-ups, } 15 \text { student wax-ups } \\
\text { and } 15 \text { dentoform teeth; visual grading } \\
\text { was performed by two experienced } \\
\text { faculty members, digital grading by one } \\
\text { operator, both gradings were repeated } \\
\text { after } 1 \text { week; maxillary 1st molar } \\
\text { wax-up (from faculty) with highest } \\
\text { scores from visual grading was used as } \\
\text { master model for digital grading. }\end{array}$ & $\begin{array}{c}\text { Modest intra-rater reliability for } \\
\text { visual scoring with similar rating } \\
\text { between the two trials (0.7); low } \\
\text { inter-rater agreement between the } \\
\text { two faculty raters; digital grading } \\
\text { showed high intra-rater } \\
\text { agreement for the repeated } \\
\text { assessment (ICC 0.9); modest } \\
\text { correlation between visual and } \\
\text { digital grading. }\end{array}$ \\
\hline $\begin{array}{l}\text { Garrett et al. } \\
2015 \text { [48] }\end{array}$ & CCS & $\mathrm{P}$ & 57 & $\begin{array}{l}\text { Evaluated E4D software (Planmeca) to } \\
\text { assess incisor and molar wax-ups of } 57 \\
\text { students, who used digital images for } \\
\text { self-assessment, and compare to faculty } \\
\text { members; based on five assessment } \\
\text { criteria (arch alignment, proximal } \\
\text { contacts, proximal contour and } \\
\text { embrasures, facial contour, lingual } \\
\text { contour) and applying 300, 400, and } 500 \\
\mu \mathrm{m} \text { level of tolerance in E4D. }\end{array}$ & $\begin{array}{l}\text { Students' self-assessment of the } \\
\text { maxillary incisor wax-up was } \\
\text { higher than faculty and E4D300, } \\
\text { but lower than E4D } 400 \text { and 500. } \\
\text { For the molar wax-up, } \\
\text { self-assessment was not different } \\
\text { to faculty, but higher than E4D300. } \\
\text { E4D500 evaluations were sig. } \\
\text { superior than other assessments. }\end{array}$ \\
\hline
\end{tabular}


Table 2. Cont.

\begin{tabular}{|c|c|c|c|c|c|}
\hline Study (Year) & Study Design & Theory/Practice & Participants & Materials and Methods & Results \\
\hline $\begin{array}{l}\text { Callan et al. } \\
2015 \text { [34] }\end{array}$ & CCS & $\mathrm{P}$ & 82 & $\begin{array}{l}\text { Validated E4D software (Planmeca) to } \\
\text { assess molar crown preparation of } 82 \\
\text { students and compare to calibrated faculty } \\
\text { members based on four criteria (occlusal } \\
\text { reduction, proximal reduction, } \\
\text { facial/lingual reduction, margins and draw). } \\
\text { Agreement in rankings between faculty } \\
\text { scores and E4D Compare scores was } \\
\text { measured with Spearman's correlation } \\
\text { coefficient (SCC) at five different tolerance } \\
\text { levels }(0.1-0.5 \mathrm{~mm}) \text {. }\end{array}$ & $\begin{array}{l}\text { SCC values for practical exams } \\
\text { varied between } 0.20 \text { and } 0.56 \text {. } \\
\text { None of the upper } 95 \% \text { confidence } \\
\text { limits reached the for strong } \\
\text { correlation. SCC values indicated } \\
\text { only weak to moderate agreement } \\
\text { in ranks between practical exam } \\
\text { scores and scores obtained with } \\
\text { E4D Compare. When ranked from } \\
\text { lowest to highest, the results from } \\
\text { the conventional grading by the } \\
\text { faculty did not correlate within an } \\
\text { acceptable range to E4D Compare } \\
\text { software data. }\end{array}$ \\
\hline $\begin{array}{l}\text { Mays et al. } \\
2016 \text { [42] }\end{array}$ & CCS & $\mathrm{P}$ & 50 & $\begin{array}{l}\text { Validated E4D software (Planmeca) to } \\
\text { assess occlusal convergence (TOC) of } 50 \\
\text { molar crown preparations from students } \\
\text { and compared to traditional } \\
\text { faculty assessment. }\end{array}$ & $\begin{array}{c}\text { Digital software could distinguish } \\
\text { differences in TOC, which were } \\
\text { grouped as minimum taper (mean } \\
\left.11^{\circ}\right) \text {, moderate }\left(\text { mean } 23^{\circ}\right) \text {, or } \\
\text { excessive }\left(\text { mean } 47^{\circ}\right) \text {. Digital TOC } \\
\text { evaluation was more objective } \\
\text { compared to faculty } \\
\text { visual scoring. }\end{array}$ \\
\hline $\begin{array}{c}\text { Gratton et al. } \\
2016 \text { [45] }\end{array}$ & RCT & $\mathrm{P}$ & 80 & $\begin{array}{l}\text { Compared effect of access to digital systems } \\
\text { in addition to conventional preparation } \\
\text { instructions; CEREC prepCheck }(n=20), \\
\text { E4D Compare }(n=20) \text {, and control without } \\
\text { access to digital system }(n=40) \text {; incisor and } \\
\text { molar crown preparations were assessed by } \\
\text { the students, by } 3 \text { faculties and by E4D } \\
\text { Compare at } 0.30 \mathrm{~mm} \text { tolerance. }\end{array}$ & $\begin{array}{l}\text { All groups had similar } \\
\text { preparation scores. Visual and } \\
\text { digital assessment scores showed } \\
\text { modest correlation. }\end{array}$ \\
\hline $\begin{array}{c}\text { Gratton et al. } \\
2017 \text { [46] }\end{array}$ & RCT & $\mathrm{P}$ & 79 & $\begin{array}{l}\text { Compared digital systems Compare }(n= \\
42) \text { and prepCheck }(n=37) \text { as additional } \\
\text { evaluation tool assessing their crown } \\
\text { preparations (maxillary central incisor and } \\
\text { mandibular molar); all preparations were } \\
\text { graded by faculty Compare and prepCheck; } \\
\text { feed-back with post-course questionnaire. }\end{array}$ & $\begin{array}{l}\text { Both groups had similar technical } \\
\text { scores; both systems had modest } \\
\text { correlation with faculty scores and } \\
\text { strong correlation with each other } \\
55.3 \% \text { of students felt unfavorable } \\
\text { about learning digital evaluation } \\
\text { protocols, while } 62.3 \% \text { felt } \\
\text { favorable about the integration of } \\
\text { the tools into the curriculum. }\end{array}$ \\
\hline $\begin{array}{l}\text { Kateeb et al. } \\
2017[38]\end{array}$ & OT & $\mathrm{P}$ & 96 & $\begin{array}{l}\text { Compared digital assessment software of } \\
\text { students' crown preparation with } \\
\text { traditional visual inspection; four } \\
\text { examiners; sample of } 20 \text { preparations were } \\
\text { reassessed for intra-rater reliability. }\end{array}$ & $\begin{array}{c}\text { Intra-rater reliability (ICC) was } \\
0.73-0.78 \text { and } 0.99 \text { for the digital } \\
\text { grading system; inter-rater } \\
\text { reliability among the four } \\
\text { examiners was good (0.76); } \\
\text { agreement between examiners } \\
\text { and digital ratings were low to } \\
\text { moderate; digital grading was } \\
\text { more consistent. }\end{array}$ \\
\hline $\begin{array}{c}\text { Sly et al. } 2017 \\
\text { [50] }\end{array}$ & OT & $\mathrm{P}$ & 98 & $\begin{array}{l}\text { Compared E4D software (Planmeca) to } \\
\text { assess students intracoronal Class I } \\
\text { preparation with traditional visual } \\
\text { inspection; four examiners. }\end{array}$ & $\begin{array}{l}\text { Similar results for grading of } \\
\text { isthmus width and remaining } \\
\text { marginal ridge, while pulpal floor } \\
\text { depth was assessed more } \\
\text { precisely with visual inspection; } \\
\text { results indicate that software has } \\
\text { limitations for intracoronal cavity } \\
\text { assessment but offers a } \\
\text { self-assessment tool to improve } \\
\text { psychomotor skills with } \\
\text { independent and } \\
\text { immediate feedback. }\end{array}$ \\
\hline
\end{tabular}


Table 2. Cont.

\begin{tabular}{|c|c|c|c|c|c|}
\hline Study (Year) & Study Design & Theory/Practice & Participants & Materials and Methods & Results \\
\hline $\begin{array}{c}\text { Kozarovska \& } \\
\text { Larsson } 2018 \\
\text { [39] }\end{array}$ & $\mathrm{RCT}$ & $\mathrm{P}$ & 57 & $\begin{array}{l}\text { Evaluated a digital preparation validation } \\
\text { tool (PVT) for students' self-assessment of } \\
\text { crown preparation (tooth } 11 \text { and 21); group } \\
\text { A (“prep-and-scan" self-assessed and } \\
\text { scanned three preparations; group B } \\
\text { ("best-of-three") self-assessed the three } \\
\text { attempts, chose the best for scanning; } \\
\text { questionnaire about students' and teachers' } \\
\text { experiences with PVT. }\end{array}$ & $\begin{array}{l}\text { Group A showed an increase in } \\
\text { agreement of self-assessment and } \\
\text { feedback from PVT, while group B } \\
\text { showed low level agreement with } \\
\text { PVT. Bucco-incisal reduction, } \\
\text { reduction of the tuberculum } \\
\text { surface and presence of undercuts } \\
\text { were difficult to correctly identify } \\
\text { by the students. Questionnaire } \\
\text { feedback revealed need for PVT to } \\
\text { develop skills, to ease assessment, } \\
\text { while critical aspects were PVT's } \\
\text { time efficiency and the need for } \\
\text { verbal feedback. Teachers } \\
\text { observed the PVT as a motivation } \\
\text { during skills laboratory training, } \\
\text { while verbal feedback were still } \\
\text { deemed necessary. }\end{array}$ \\
\hline $\begin{array}{c}\text { Lee et al. } 2018 \\
\text { [51] }\end{array}$ & OT & $\mathrm{P}$ & 69 & $\begin{array}{l}\text { Compared students' self-assessment } \\
\text { (conventional and digital with Cerec } \\
\text { software) with assessment (conventional } \\
\text { and digital) by faculty members for class II } \\
\text { amalgam preparations (C2AP) and Class III } \\
\text { composite preparations (C3CP). }\end{array}$ & $\begin{array}{l}\text { Students overestimated their } \\
\text { performance (positive S-F gap) in } \\
\text { both the C2AP and C3CP } \\
\text { preparation exercises in } \\
\text { conventional (11\% and } 5 \% \text { ) and } \\
\text { digital assessments ( } 8 \% \text { and } 2 \% \text { ); } \\
\text { in conventional assessments, } \\
\text { preclinical performance was } \\
\text { negatively correlated with } \\
\text { student-faculty gap ( } \mathrm{r}=-0.47, p< \\
0.001) \text {; particularly students in the } \\
\text { bottom quartile sig. improved } \\
\text { their self-assessment accuracy } \\
\text { using digital self-assessments } \\
\text { over conventional assessments. }\end{array}$ \\
\hline $\begin{array}{c}\text { Liu et al. } 2018 \\
\text { [41] }\end{array}$ & RCT & $\mathrm{P}$ & 66 & $\begin{array}{l}\text { Evaluated the effectiveness of preclinical } \\
\text { training on ceramic crown preparation } \\
\text { using digital training system compared } \\
\text { with traditional training method; test } \\
\text { group: trained with digital method with } \\
\text { Online Peer-Review System (OPRS) and } \\
\text { Real-time Dental Training and Evaluation } \\
\text { System (RDTES); control group: traditional } \\
\text { method with instructor demonstration and } \\
\text { evaluation; central incisor } \\
\text { crown preparation. }\end{array}$ & $\begin{array}{l}\text { Five of } 15 \text { assessed items were } \\
\text { significantly better in test group; } \\
96.97 \% \text { of test students agreed or } \\
\text { strongly agreed that using digital } \\
\text { training system could better } \\
\text { improve the practical ability than } \\
\text { traditional method. }\end{array}$ \\
\hline $\begin{array}{c}\text { Greany et al. } \\
2019 \text { [36] }\end{array}$ & OT & $\mathrm{P}$ & 67 & $\begin{array}{l}\text { Compared conventional visual faculty } \\
\text { inspection of wax-ups to digital assessment; } \\
\text { six examiners evaluated } 67 \text { students' } \\
\text { wax-ups of maxillary first molar, } \\
\text { reevaluation after } 1 \text { week; scan with IOS, } \\
\text { STL files imported to free available open } \\
\text { source data cloud comparison utility } \\
\text { (Cloud Compare.org), digital evaluation by } \\
\text { two examiners. }\end{array}$ & $\begin{array}{c}\text { Visual inspection had low } \\
\text { inter-examiner precision (ICC } \\
0.332 \text { ) and accuracy; } \\
\text { intra-examiner precision for } \\
\text { reevaluation was low; } \\
\text { inter-examiner precision of digital } \\
\text { exam was high (ICC } 0.866 \text { ) with } \\
\text { high accuracy. }\end{array}$ \\
\hline
\end{tabular}


Table 2. Cont.

\begin{tabular}{|c|c|c|c|c|c|}
\hline Study (Year) & Study Design & Theory/Practice & Participants & Materials and Methods & Results \\
\hline $\begin{array}{l}\text { Miyazone et al. } \\
2019 \text { [43] }\end{array}$ & OT & $P$ & 100 & $\begin{array}{l}\text { Compared prepCheck with visual } \\
\text { faculty assessment of students' crown } \\
\text { preparation of typodont teeth } \\
\text { (mandibular first molar as crown } \\
\text { abutment, maxillary 2nd premolar and } \\
\text { 2nd molar as FDP abutments), assess } \\
\text { inter- and intra-grader agreement of } \\
\text { five experienced examiners conducting } \\
\text { visual and digital exam; scoring } \\
\text { repeated three times; parameters for } \\
\text { crown abutments: axial tissue removal, } \\
\text { margin width, undercut, occlusal } \\
\text { reduction, cusp tips, occlusal anatomy; } \\
\text { for FDP abutments: path of insertion. }\end{array}$ & $\begin{array}{l}\text { Intra-grader agreement was better } \\
\text { with prepCheck than visual } \\
\text { assessment for all parameters } \\
\text { except cusp tip and occlusal } \\
\text { anatomy; inter-grader agreement } \\
\text { for path of insertion was } \\
\text { questionable with visual, but } \\
\text { good with digital assessment. } \\
\text { Inter-grader disagreement was } \\
\text { greater in visual than digital } \\
\text { assessment. Overestimation of } \\
\text { tooth reduction in visual grading } \\
\text { was eliminated by digital analysis. }\end{array}$ \\
\hline
\end{tabular}

RCT = Randomized Controlled Trial; CT = Controlled Trial; CS = Cohort Study; CCS = Case-Control-Study; $\mathrm{OT}=$ Observational Study; ICC = Inter-Class Correlation; STL = Standard Tessellation Language.

\subsection{Dental Simulator Motor Skills Including Intraoral Optical Scanning}

A high level of interest and acceptance was documented among undergraduate students for simulator training in cavity preparations [54-56], or in surgical interventions such as apicoectomies (Table 3) [57]. A trend toward improved technical skills and ergonomics was documented when simulator training with real-time feedback was added to traditional instructions [58-60]. Training with a VR-based simulator improved students' preparation of class I occlusal cavities [61], and of abutments for porcelain-fused-to-metal crowns [62]. In evaluating the manual dexterity of students, professionals, and non-professionals, the simulator scoring algorithm showed a high reliability to differentiate between non-professionals and dental students or dentists [63]. Instruction time from faculty for teaching cavity and crown preparations was significantly reduced when virtual reality computer-assisted simulation systems were used compared to contemporary non-computer-assisted simulation systems [64]. Preparation performance on VR units with continuous evaluations and advice from clinical instructors led to better preparation quality than real-time feedback from the virtual dental unit. Self-paced learning and the immediate software feedback were beneficial with the VR unit, and it was perceived as adjunct, but not replacing faculty instructions [65]. Students requested software improvements with more realistic force feedback during interaction with different tissues in the virtual oral environment including the maxilla, mandible, gum, tongue, cheek, enamel, dentine, pulp, cementum, etc. [66]. Recent advancements of simulators enabled variations in force feedback accounting for varying hardness of the virtual material, cut speed gain, and push force [67].

Improved student performance in crown digitization and framework design was observed when CAD/CAM (Computer-Aided Design/ Computer-aided manufacturing) courses were introduced in dental education [68]. While students enjoyed designing a full crown using CAD as compared to traditional waxing, limits of the technology in representing anatomic contours and excursive occlusion were identified [69]. Viewing their scanned crown preparations magnified on the screen improved students' understanding of the finishing line [70]. The application of IOS in the simulation training showed that even inexperienced dental students were capable of acquiring the skills needed to use digital tools, and students preferred IOS over conventional impressions [71,72]. Furthermore, students' work time was shorter with IOS than with conventional impression [72,73], although more teaching time was required for digital scanning than for conventional impression techniques [74]. Applying digital complete denture treatment (AvaDent; AvaDent Digital Dental Solutions, Scottsdale, AZ, USA) in the student clinics resulted in restorations with superior gradings that were preferred by both students and patients [75]. Using an intraoral camera increased patients' consent for crown treatment, and was positively perceived by students and patients, while faculty members were neutral [76]. 
Table 3. Dental simulator motor skills incl. IOS $(n=23)$.

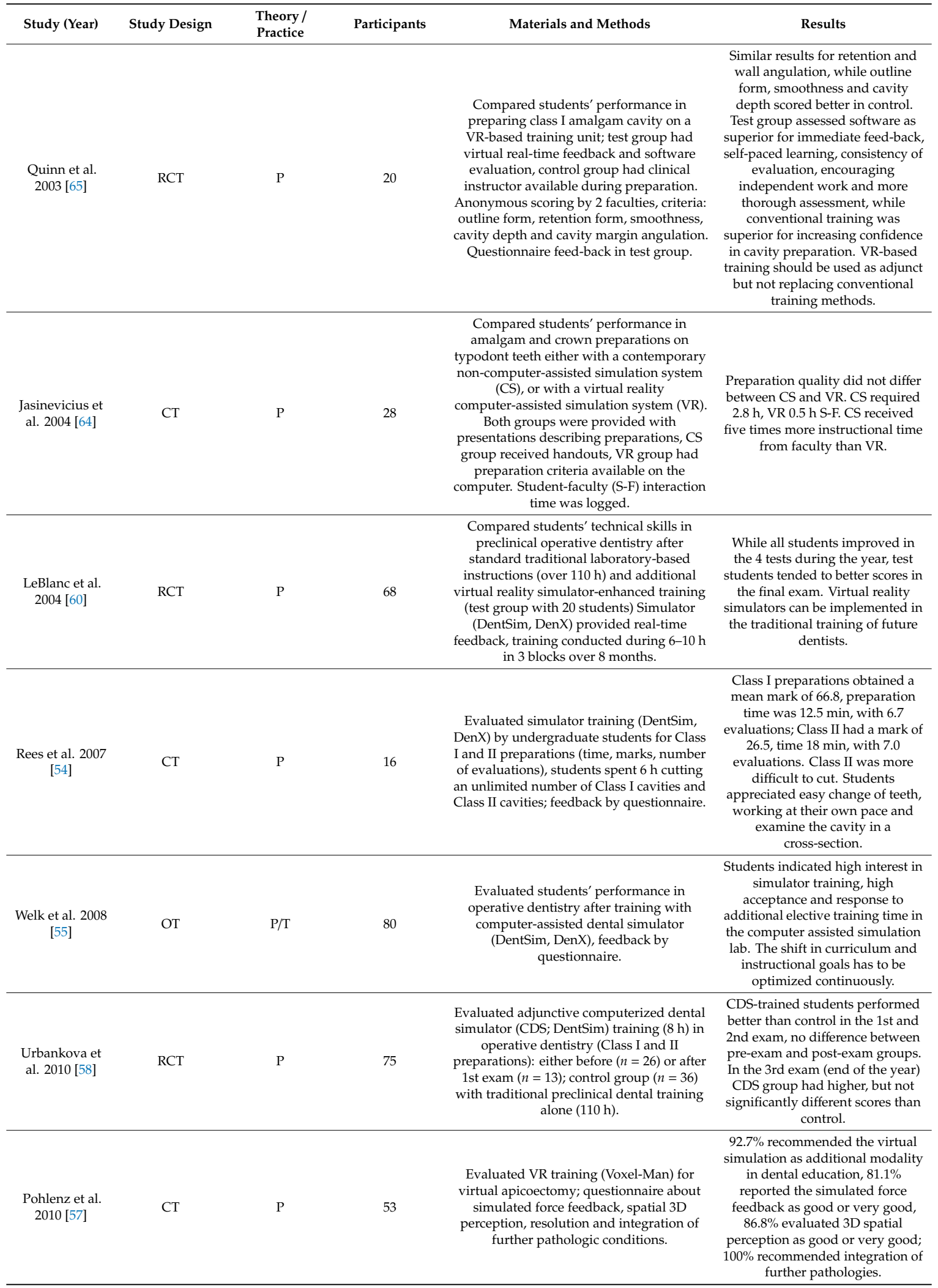


Table 3. Cont.

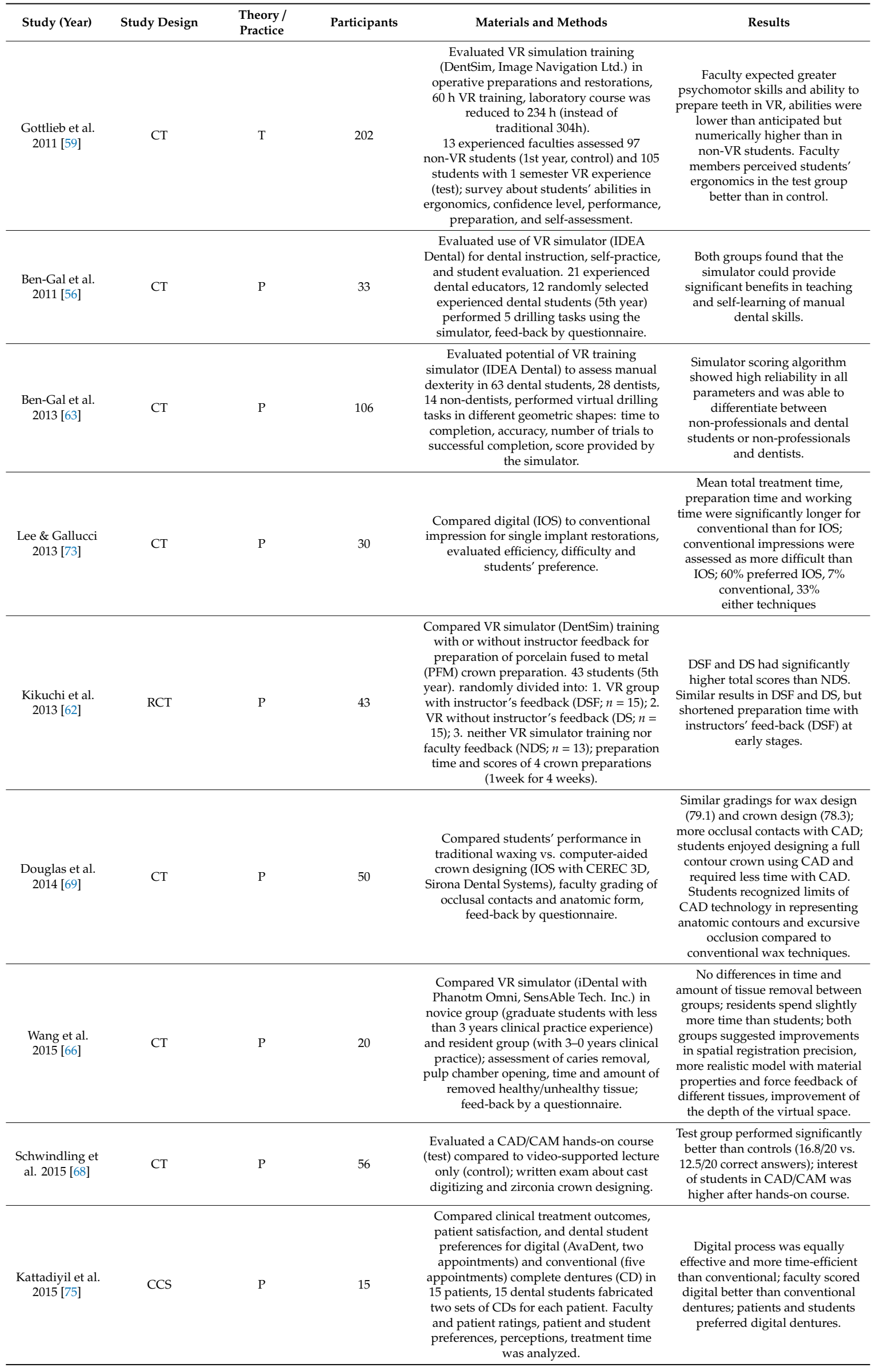


Table 3. Cont.

\begin{tabular}{|c|c|c|c|c|c|}
\hline Study (Year) & Study Design & $\begin{array}{l}\text { Theory / } \\
\text { Practice }\end{array}$ & Participants & Materials and Methods & Results \\
\hline $\begin{array}{l}\text { Wegner et al. } \\
2017[70]\end{array}$ & OT & $\mathrm{P}$ & 108 & $\begin{array}{l}\text { Evaluated students' perception } \\
\text { (questionnaire feedback) of IOS (Lava Cos } \\
\text { Training, 3M Espe), scanning of } 3 \text { typodont } \\
\text { tooth preparations. }\end{array}$ & $\begin{array}{l}63.9 \% \text { positive opinion, } 60.2 \% \\
\text { considered scanning process as } \\
\text { manageable, } 55.6 \% \text { profited from } \\
\text { magnified view of their } \\
\text { preparation to understand } \\
\text { chamfer finish lines. }\end{array}$ \\
\hline $\begin{array}{l}\text { Schott et al. } \\
2019 \text { [71] }\end{array}$ & OT & $\mathrm{P}$ & 31 & $\begin{array}{l}\text { Evaluated dental students' perception of } \\
\text { IOS compared to conventional alginate } \\
\text { impression; survey after basic training and } \\
\text { self-practicing. }\end{array}$ & $\begin{array}{l}77 \%(24) \text { students were overall } \\
\text { "very" or "rather satisfied" with } \\
\text { the handling of IOS; } 58 \% \\
\text { preferred IOS from the dentist's } \\
\text { perspective, no significant } \\
\text { difference from the patient's } \\
\text { perspective but reduced comfort } \\
\text { related to the impression tray. }\end{array}$ \\
\hline $\begin{array}{c}\text { Murbay et al. } \\
2020[61]\end{array}$ & RCT & $\mathrm{P}$ & 32 & $\begin{array}{c}\text { Incorporated VR with Moog Simodont } \\
\text { dental trainer in preclinical training; } \\
\text { students performed an occlusal preparation } \\
\text { on typodont teeth and had previous } \\
\text { exposure to VR (group 1) or no VR } \\
\text { exposure (group 2); assessment was } \\
\text { conducted (satisfactory / unsatisfactory) by } \\
\text { manual approach or digital (Magic 19.01 } \\
\text { 64-bit). }\end{array}$ & $\begin{array}{l}\text { VR use improved preparation } \\
\text { significantly with } 75 \%(12 / 16) \\
\text { satisfactory preparations in group } \\
1 \text { and } 44 \% \text { (7/16) in group } 2 . \\
\text { Manual and digital evaluation } \\
\text { methods did not differ } \\
\text { significantly. }\end{array}$ \\
\hline $\begin{array}{c}\text { Murrell et al. } \\
2019 \text { [76] }\end{array}$ & OT & $\mathrm{P}$ & 288 & $\begin{array}{l}\text { Evaluated completion of posterior crown } \\
\text { planning with or without presenting the } \\
\text { situation to the patient by intraoral camera } \\
\text { use; } 51 \text { students completed } 198 \text { surveys, } 35 \\
\text { faculty members with } 64 \text { surveys, } 202 \\
\text { patient surveys, survey was voluntary and } \\
\text { camera use optional. }\end{array}$ & $\begin{array}{l}\text { Positive perception of intraoral } \\
\text { camera use by students and } \\
\text { patients, while faculty was } \\
\text { neutral; significantly higher } \\
\text { completion rate when intraoral } \\
\text { camera was used. }\end{array}$ \\
\hline
\end{tabular}

RCT = Randomized Controlled Trial; CT = Controlled Trial; CS = Cohort Study; CCS = Case-Control-Study; OT = Observational Study; DSF = VR group with instructor feedback; DS = VR group without instructor feedback; NDS = Neither VR simulator training nor faculty feedback; VAS = Visual Analog Scale; IDEA = International Dental Education Association. 


\subsection{D Rapid Prototyping}

Two studies evaluated training models created by 3D rapid prototyping $[77,78]$. Such methods can supplement teaching on human teeth or even replace it, and educational needs can easily be adapted to students' skills (Table 4).

Table 4. Group 4: 3D printing and prototyping $(n=2)$.

\begin{tabular}{|c|c|c|c|c|c|}
\hline Study (Year) & Study Design & Theory/Practice & Participants & Materials and Methods & Results \\
\hline Soares et al. 2013 [77] & OT & $\mathrm{T}$ & 40 & $\begin{array}{l}\text { Cavity preparation was taught with } \\
\text { conventional teaching materials with } 2 \mathrm{D} \\
\text { schematic illustration and photographs. } \\
\text { New didactic material with virtual 3D } \\
\text { (videos of the preparations) and magnified } \\
\text { nylon prototyped models was introduced. } \\
\text { Evaluation by questionnaire. }\end{array}$ & $\begin{array}{l}\text { Improvement of teaching } \\
\text { quality when combining } \\
\text { 3D virtual technology with } \\
\text { real models. }\end{array}$ \\
\hline
\end{tabular}

$\mathrm{RCT}=$ Randomized Controlled Trial; CT = Controlled Trial; CS = Cohort Study; CCS = Case-Control-Study; OT $=$ Observational Study.

\subsection{Digital Radiography}

Four studies dealt with diagnosing radiographic changes [79-81] or detecting positional errors on panoramic radiographs [82] (Table 5). Senior students showed a poor ability for approximal caries detection on both conventional and digital radiographs when compared to histo-pathologic analysis from sectioned teeth [80]. One study demonstrated that digital learning supported the development of students' diagnostic skills [81]. Another study showed that the accuracy of radiographic caries detection was improved by a computer-assisted learning calibration program, which provided feedback illustrating the actual tooth surface condition [79]. In one study, two digital systems for endodontic tooth length measurements were compared, and students' positive attitudes towards digital radiography were documented [83].

Table 5. Group 5: Digital Radiology $(n=5)$.

\begin{tabular}{cccccc}
\hline Study (Year) & Study Design & Theory/Practice & Participants & Materials and Methods & Results \\
\hline & & & CAL improved students' \\
diagnostic performance; true \\
positive ratio (sensitivity) for \\
caries detection was significantly \\
hileman et al.
\end{tabular}


Table 5. Cont.

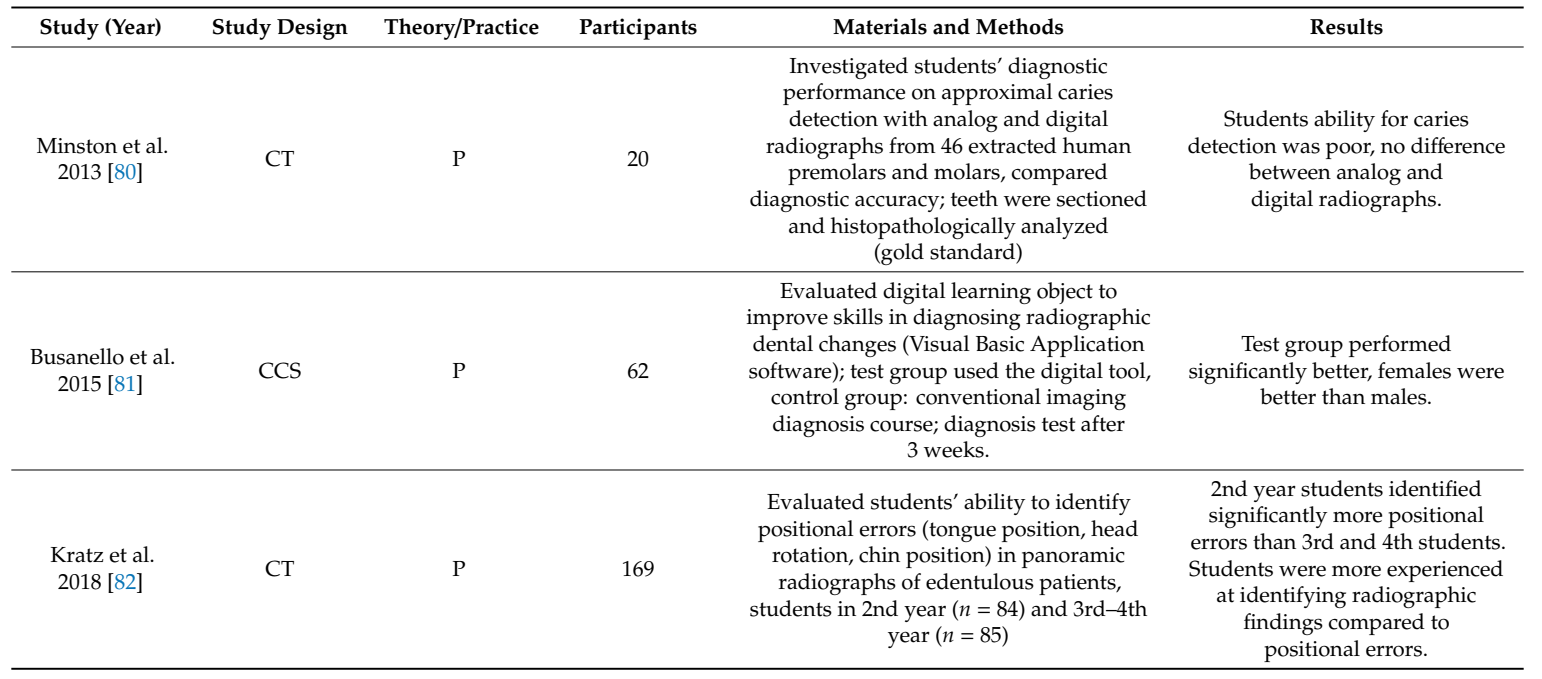

RCT = Randomized Controlled Trial; CT = Controlled Trial; CS = Cohort Study; CCS = Case-Control-Study; OT = Observational Study; CCD = Charged Couple Device; PSP = Photostimulable Phosphor.

\subsection{Surveys Related to the Penetration and Acceptance of Digital Education}

Six surveys evaluated students' perception and acceptance of digital technologies (Table 6) [84-89]. The more recent studies reflected that digital technologies have become established teaching tools, particularly in the field of digital radiography and microscopy, and the use of textbooks decreased; simulation training was preferred [86,87].

Table 6. Surveys related to digital education $(n=10)$.

\begin{tabular}{|c|c|c|c|c|c|}
\hline Study (Year) & Study Design & Theory/Practice & Participants & Materials and Methods & Results \\
\hline $\begin{array}{l}\text { Scarfe et al. } \\
1996 \text { [88] }\end{array}$ & OT & $\mathrm{T}$ & 277 & $\begin{array}{l}\text { Investigated the effects of } \\
\text { instructions in intraoral digital } \\
\text { radiology on dental students' } \\
\text { knowledge, attitudes and beliefs; } \\
174 \text { from a university with formal } \\
\text { instruction on digital dental } \\
\text { radiography, and } 103 \text { from a } \\
\text { university without instructions. }\end{array}$ & $\begin{array}{l}\text { Students with instructions knew } \\
\text { significantly more than students without; } \\
93 \% \text { wanted digital radiology to be } \\
\text { included in the dental curriculum. }\end{array}$ \\
\hline $\begin{array}{l}\text { Jathanna et al. } \\
2014 \text { [84] }\end{array}$ & OT & $\mathrm{T}$ & 186 & $\begin{array}{l}\text { Surveyed the perception of Indian } \\
\text { dental students toward usefulness } \\
\text { of digital technologies in } \\
\text { improving dental practice, } \\
\text { willingness to use digital and } \\
\text { electronic technologies, perceived } \\
\text { obstacles to use digital and } \\
\text { electronic technologies in dental } \\
\text { care setups, and their attitudes } \\
\text { toward internet privacy issues. }\end{array}$ & $\begin{array}{l}\text { Students indicated that digital technology } \\
\text { increases patient satisfaction and practice } \\
\text { efficiency, improves record quality, } \\
\text { doctor-doctor communication, case } \\
\text { diagnosis and treatment planning; } \\
\text { obstacles to the wide adoption of these } \\
\text { technologies were cost and dentists' lack of } \\
\text { knowledge and comfort with technology. }\end{array}$ \\
\hline $\begin{array}{l}\text { Chatham et al. } \\
2014 \text { [90] }\end{array}$ & OT & $\mathrm{T}$ & 11 & $\begin{array}{l}\text { Surveyed the penetration of } \\
\text { digital technologies in UK dental } \\
\text { schools (11/16 responded). }\end{array}$ & $\begin{array}{l}45 \% \text { did not teach digital technologies ( } 36 \% \\
\text { because it was not part of the curriculum, } \\
\text { or in } 95 \% \text { due to the lack of technical } \\
\text { expertise or support); half of those teaching } \\
\text { digital technologies did so with lectures or } \\
\text { demonstrations, the other half allowed } \\
\text { practical involvement. }\end{array}$ \\
\hline
\end{tabular}


Table 6. Cont.

\begin{tabular}{|c|c|c|c|c|c|}
\hline Study (Year) & Study Design & Theory/Practice & Participants & Materials and Methods & Results \\
\hline $\begin{array}{l}\text { Brownstein et } \\
\text { al. } 2015 \text { [91] }\end{array}$ & OT & $\mathrm{T}$ & 33 & $\begin{array}{l}\text { Surveyed the penetration of } \\
\text { emerging dental technologies into } \\
\text { the curricula at US dental schools } \\
\text { (62 eligible schools were } \\
\text { contacted); academic Deans } \\
\text { answered } 19 \text { questions related to } \\
12 \text { dental topics); } 19 \text { schools had } \\
<100 \text { students/class; } 14 \text { had } \\
>100 \text { students. }\end{array}$ & $\begin{array}{c}\text { Highest penetration was in preclinical didactic } \\
\text { courses }(62 \%) \text { and lowest was in preclinical } \\
\text { laboratory ( } 36 \%) \text {; most common specific } \\
\text { technologies were digital radiography }(85 \%) \\
\text { and rotary endodontics }(81 \%) \text {, least common } \\
\text { were CAD/CAM denture fabrication }(20 \%) \text { and } \\
\text { hard tissue lasers ( } 24 \%) \text {; the bigger the class } \\
\text { sizes (>100 students) and the older the school, } \\
\text { the lower the incorporation of } \\
\text { newer technologies. }\end{array}$ \\
\hline $\begin{array}{c}\text { Bhardwaj et al. } \\
2015 \text { [92] }\end{array}$ & OT & $\mathrm{T}$ & 54 & $\begin{array}{l}\text { Surveyed faculties' opinion (15 } \\
\text { dental, } 42 \text { medical faculty } \\
\text { members in Melaka, Malaysia) } \\
\text { toward the existing e-learning } \\
\text { activities, and to analyze the } \\
\text { extent of adopting and integration } \\
\text { of e-learning into their traditional } \\
\text { teaching methods; questionnaire } \\
\text { with socio-demographic profile, } \\
\text { skills and aptitude on the use of } \\
\text { computer, knowledge and use of } \\
\text { existing e-learning technology } \\
\text { (e.g., MOODLE), experiences and } \\
\text { attitudes towards e-learning, } \\
\text { faculty opinion on novel } \\
\text { e-learning techniques, and } \\
\text { initiatives to be adopted for } \\
\text { optimization of existing } \\
\text { e-learning facilities. }\end{array}$ & $\begin{array}{l}65.4 \% \text { of faculty was positive towards } \\
\text { e-learning; formal training required to support } \\
\text { e-learning that enables smooth transition of the } \\
\text { faculty from traditional teaching into blended } \\
\text { approach; traditional instructor centered } \\
\text { teaching is shifting to learner centered model } \\
\text { facilitating students to control their own } \\
\text { learning. Popular e-learning education tools: } \\
\text { Virtual Learning Environment systems such as } \\
\text { WebCT }\end{array}$ \\
\hline $\begin{array}{c}\text { Ren et al. } 2017 \\
\text { [86] }\end{array}$ & OT & $\mathrm{T}$ & 389 & $\begin{array}{c}\text { Questionnaire assessed students' } \\
\text { attitudes towards digital } \\
\text { simulation technologies and } \\
\text { teaching methods, how students } \\
\text { compare digital technologies with } \\
\text { traditional training methods; four } \\
\text { categories: digital microscope, } \\
\text { virtual pathology slides, digital } \\
\text { radiology, virtual } \\
\text { simulation training. }\end{array}$ & $\begin{array}{l}\text { Most students accepted digital technologies as } \\
\text { stimulating tool for self-learning; digital X-ray } \\
\text { images were used to study oral radiology and } \\
\text { preferred to conventional X-rays. Dental } \\
\text { simulation training was most preferred } \\
\text { technology ( } 54.6 \%), 16.7 \% \text { preferred digital } \\
\text { microscopy, } 15.0 \% \text { virtual pathology slides, } \\
13.7 \% \text { digital x-ray images. } 76 \% \text { used the } \\
\text { virtual simulation training machine to study } \\
\text { oral clinical skills; } 61 \% \text { felt that the simulator } \\
\text { would be a useful addition to current } \\
\text { pre-clinical training; } 66 \% \text { felt that the simulator } \\
\text { provided a realistic virtual environment. }\end{array}$ \\
\hline $\begin{array}{l}\text { Prager \& Liss } \\
\quad 2019[2]\end{array}$ & OT & $\mathrm{T}$ & 54 & $\begin{array}{l}\text { Surveyed the extent of teaching } \\
\text { digital modalities and use for } \\
\text { patient care in dental schools ( } 54 \\
\text { out of } 76 \text { dental schools in U.S. } \\
\text { and Canada responded) in } \\
\text { February } 2019 .\end{array}$ & $\begin{array}{l}93 \% \text { used CAD/CAM digital scanning, IOS was } \\
\text { performed exclusively in } 55 \% \text {, extraoral model } \\
\text { scan was used as sole technique in } 8 \% \text {, intra- } \\
\text { and extraoral scanning in } 37 \% \text { of the schools. } \\
\text { IOS was applied for crowns }(100 \%), \\
\text { inlays/onlays ( } 77 \% \text { ), implant crowns }(52 \%), \\
\text { fixed partial denture ( } 34 \% \text { ), complete denture } \\
(2 \%) \text {, but none of the schools indicated to use } \\
\text { IOS always for crowns. } 59 \% \text { had a digital } \\
\text { workflow established to deliver same-day } \\
\text { restorations. } 34 \% \text { had at least } 10 \% \text { of faculty } \\
\text { proficient in IOS, } 66 \% \text { had } 10 \% \text { or less. }\end{array}$ \\
\hline $\begin{array}{l}\text { Turkyilmaz et } \\
\text { al. } 2019 \text { [89] }\end{array}$ & OT & $\mathrm{T}$ & 255 & $\begin{array}{l}\text { Surveyed students' perception of } \\
\text { e-learning impact on dental } \\
\text { education, response rate of } 22.6 \% \\
\text { ( } 255 \text { out of } 1130 \text { electronically } \\
\text { distributed 14-question surveys to } \\
\text { 2nd-4th year students). }\end{array}$ & $\begin{array}{l}48.6 \% \text { preferred traditional lecture mixed with } \\
\text { online learning, } 18.4 \% \text { online classes only, } \\
18.0 \% \text { traditional lecture style only; greatest } \\
\text { impact on learning had YouTube, Bone Box, } \\
\text { and Google. } 60 \% \text { spent between } 1 \text { and }>4 \mathrm{~h} \text { per } \\
\text { day on electronic resources for academic } \\
\text { performance. E-learning had a significant } \\
\text { perceived effect on didactic and clinical } \\
\text { understanding. Students observed that } \\
\text { faculties estimated }<50 \text { years of age were more } \\
\text { likely to incorporate e-learning into courses } \\
\text { and more likely to use social media for } \\
\text { communication. }\end{array}$ \\
\hline
\end{tabular}

RCT = Randomized Controlled Trial; CT = Controlled Trial; CS = Cohort Study; CCS = Case-Control-Study; OT = Observational Study. 
Four surveys analyzed the penetration of and attitudes towards digital technologies at dental schools in the UK [90], U.S. [91], North America [2], or among the faculty staff at a dental school in Malaysia [92]. According to the most recent survey, CAD/CAM technologies were taught in most dental schools in North America (93\%), while other digital modalities showed less penetration [2].

Despite a high acceptance of digital technologies in dental education by faculty [92] and students [86], it was concluded that e-resources should not replace interactions with faculty; students wanted lectures and clinical procedures recorded [85].

\section{Discussion}

The systematic review aimed to investigate current penetration and educational quality enhancements from digitalization in the dental curriculum. Heterogeneous study types addressing various fields of digital applications were found. While a meta-analysis was not feasible, a descriptive approach for identified publications was conducted.

Digitalization in dental education is frequently used to enhance the accessibility and exchange of documents and to facilitate the collaboration and communication among students, teachers, and administrative staff. Digitalization enables cloud-based records, evaluation, and feedback, as well as the provision of e-learning modules [23]. Students today, particularly the Millennials, expect services instantly, expect to be able to download their grades, course schedules, and other information automatically, and to be able to get assistance $24 \mathrm{~h}$ a day. In order to satisfy these expectations, it is necessary to promote a change of mindset of the dental faculty and provide instructors with training in e-learning and e-teaching to enable theoretical and practical knowledge transfer [85]. The coronavirus disease (Covid-19) pandemic that started in 2019 caused dental schools around the world to close, and highlighted the need for alternative channels for education (e.g., Web-based learning platforms) [93]. Scheduled webinars can provide a structure for students' theoretical learning. Additional applications of digital features include educational videos illustrating clinical exams or therapeutic steps, interactive systems, adaptive systems that monitor students' ability and adjust teaching accordingly, online collaborative tools, etc. The use of pictograms instead of scripts in educational videos facilitates a language-independent application in several countries.

Especially in the field of motor skills training, digital software tools can be used to evaluate the manual abilities of potential candidates for the dental curriculum, to analyze students' preclinical preparations, to enable self-assessment, and to enhance the quality of education. The objective and exact nature of these digital evaluations helps to improve students' visualization, provides immediate feedback, and enhances instructor evaluation and student self-evaluation and self-correction [43,94]. Students can learn to self-assess their work with self-reflection and faculty guidance in conjunction with a specially designed digital evaluation tool [48]. IOS and digital impression techniques can be included early in the dental curriculum to help familiarize students with ongoing development in the computer-assisted technologies used in oral rehabilitation [3,72].

While undergraduate students today have to be prepared for digital dentistry, they still need to acquire the knowledge of conventional treatment strategies and processes. Growing up in the digital world, they will easily adapt to digital features. Digital dentistry offers several options for an objective standardized evaluation of students' performance, which should be used for quality enhancement. It is currently a "teaching transition time", and new standards have to be defined for dental education in general. Open questions remain, such as: (i) in which phase of the dental curricula should digital technologies be introduced as the routine tool; (ii) which analog techniques can be omitted; and iii) which digital content should be taught in which disciplines?

Several studies indicated that personal instruction and feedback from faculty cannot be replaced by simulator training and feedback $[39,65,85]$. In this context, faculty should be aware of their responsibility in teaching young dentists, who are treating individuals with individual needs requiring empathy and an informed consent for any treatment decision. Digitalization cannot replace all educational lessons or 
courses, and the role-model function of faculty is important when supervising students during patient treatment in the clinical courses.

It should be emphasized that there are still no uniform standards in dental education with regard to the digital tools applied. Such standards are essential to ensure uniformity in teaching, which is particularly important for an international exchange. Society as well as dentistry is currently undergoing a digital transformation. It is necessary to clarify learning contents, to what extent conventional workflows should still be taught, and what can be done digitally. While digital tools and applications in knowledge transfer are a general challenge for undergraduate education in all disciplines, the field of dentistry with its high degree of practical training units is specifically demanding. Just because training units are designed digitally does not mean that students learn on their own. Continuous training with supervision and feed-back is still the key to good dental education. In this context, digitization is certainly a great opportunity to convey the learning content with more joy and newly awakened enthusiasm.

Following the rule, "you can only teach what you are able to perform yourself", a highly motivated faculty is needed that is willing to embrace the latest digital technologies. Besides personal motivation, the financial aspect of implementing the various digital tools and applications has to be managed at dental universities. Collaborations with industry would be helpful here. This is a classic "win-win situation"- the dental school would be equipped with the latest products and updates, and the industry would get access to the youngest target group of potential customers. In the event of such collaborations, it is vital that universities maintain their objectivity by offering a variety of products from diverse companies; otherwise, there is a risk of unduly influencing dental students and biasing them towards one particular technological option. The rapid pace of change in dental technology must also be considered. Dental technology companies are constantly introducing new products and workflows. While this provides exciting opportunities for dental research, to test and analyze those new developments, it complicates the implementation of digital workflows in dental education programs. New job descriptions are also necessary at dental schools in order to maintain the technical infrastructures required for these new technologies and to guarantee a smooth operation in clinical practice. In future, the best dental schools will be ranked according to their digital infrastructure combined with the level of innovation of the teaching faculty.

\section{Conclusions}

Digital tools and applications are now widespread in routine dental care. Therefore, this trend towards digitization and ongoing developments must be considered in dental curricula in order to prepare future dentists for their daily work-life. There is a need to establish generally accepted digital standards of education - at least among the different dental universities within individual countries. Digitalization offers the potential to revolutionize the entire field of dental education. More interactive and intuitive e-learning possibilities will arise that motivate students and provide a stimulating, enjoyable, and meaningful educational experience with convenient access $24 \mathrm{~h}$ a day.

At present, digital dental education encompasses several areas of teaching interests, including Web-based knowledge transfer and specific technologies such as digital surface mapping, dental simulator motor skills including IOS, and digital radiography. Furthermore, it is assumed that AR/VR-technology will play a dominant role in the future development of dental education.

Supplementary Materials: The following are available online at http://www.mdpi.com/1660-4601/17/9/3269/s1, Annex S1 and Annex S2.

Author Contributions: Conceptualization, Methodology, and Writing-Original Draft Preparation, N.U.Z. and T.J.; Writing-Review and Editing, N.U.Z., T.J., L.M., and H.O.; Supervision, N.U.Z. and T.J.; Project Administration, T.J. All authors have read and agreed to the published version of the manuscript.

Funding: This research received no external funding.

Conflicts of Interest: The authors declare no conflicts of interest. 


\section{References}

1. Fernandez, M.A.; Nimmo, A.; Behar-Horenstein, L.S. Digital Denture Fabrication in Pre- and Postdoctoral Education: A Survey of U.S. Dental Schools. J. Prosthodont. 2016, 25, 83-90. [CrossRef] [PubMed]

2. Prager, M.C.; Liss, H. Assessment of Digital Workflow in Predoctoral Education and Patient Care in North American Dental Schools. J. Dent. Educ. 2019. [CrossRef]

3. Joda, T.; Lenherr, P.; Dedem, P.; Kovaltschuk, I.; Bragger, U.; Zitzmann, N.U. Time efficiency, difficulty, and operator's preference comparing digital and conventional implant impressions: A randomized controlled trial. Clin. Oral Implant. Res. 2017, 28, 1318-1323. [CrossRef] [PubMed]

4. Joda, T.; Ferrari, M.; Bragger, U.; Zitzmann, N.U. Patient Reported Outcome Measures (PROMs) of posterior single-implant crowns using digital workflows: A randomized controlled trial with a three-year follow-up. Clin. Oral Implant. Res. 2018, 29, 954-961. [CrossRef] [PubMed]

5. Muhlemann, S.; Sandrini, G.; Ioannidis, A.; Jung, R.E.; Hammerle, C.H.F. The use of digital technologies in dental practices in Switzerland: A cross-sectional survey. Swiss Dent. J. 2019, 129, 700-707.

6. Joda, T.; Zarone, F.; Ferrari, M. The complete digital workflow in fixed prosthodontics: A systematic review. BMC Oral Health 2017, 17, 124. [CrossRef]

7. Goodacre, C.J. Digital Learning Resources for Prosthodontic Education: The Perspectives of a Long-Term Dental Educator Regarding 4 Key Factors. J. Prosthodont. 2018, 27, 791-797. [CrossRef]

8. De Boer, I.R.; Wesselink, P.R.; Vervoorn, J.M. The creation of virtual teeth with and without tooth pathology for a virtual learning environment in dental education. Eur. J. Dent. Educ. 2013, 17, 191-197. [CrossRef]

9. Joda, T.; Gallucci, G.O.; Wismeijer, D.; Zitzmann, N.U. Augmented and virtual reality in dental medicine: A systematic review. Comput. Biol. Med. 2019, 108, 93-100. [CrossRef]

10. Towers, A.; Field, J.; Stokes, C.; Maddock, S.; Martin, N. A scoping review of the use and application of virtual reality in pre-clinical dental education. Br. Dent. J. 2019, 226, 358-366. [CrossRef]

11. Moher, D.; Liberati, A.; Tetzlaff, J.; Altman, D.G.; Group, P. Preferred reporting items for systematic reviews and meta-analyses: The PRISMA statement. Ann. Intern. Med. 2009, 151, 264-269. [CrossRef]

12. Komolpis, R.; Johnson, R.A. Web-based orthodontic instruction and assessment. J. Dent. Educ. 2002, 66, 650-658. [PubMed]

13. Bains, M.; Reynolds, P.A.; McDonald, F.; Sherriff, M. Effectiveness and acceptability of face-to-face, blended and e-learning: A randomised trial of orthodontic undergraduates. Eur. J. Dent. Educ. 2011, 15, 110-117. [CrossRef] [PubMed]

14. Wright, E.F.; Hendricson, W.D. Evaluation of a 3-D interactive tooth atlas by dental students in dental anatomy and endodontics courses. J. Dent. Educ. 2010, 74, 110-122. [PubMed]

15. Mitov, G.; Dillschneider, T.; Abed, M.R.; Hohenberg, G.; Pospiech, P. Introducing and evaluating MorphoDent, a Web-based learning program in dental morphology. J. Dent. Educ. 2010, 74, 1133-1139. [PubMed]

16. Curnier, F. Teaching dentistry by means of virtual reality-The Geneva project. Int. J. Comput. Dent. 2010, 13, 251-263.

17. Kingsley, K.V.; Kingsley, K. A case study for teaching information literacy skills. BMC Med. Educ. 2009,9 , 7. [CrossRef]

18. Gonzalez, S.M.; Gadbury-Amyot, C.C. Using Twitter for Teaching and Learning in an Oral and Maxillofacial Radiology Course. J. Dent. Educ. 2016, 80, 149-155.

19. Vuchkova, J.; Maybury, T.; Farah, C.S. Digital interactive learning of oral radiographic anatomy. Eur. J. Dent. Educ. 2012, 16, e79-e87. [CrossRef]

20. Schultze-Mosgau, S.; Zielinski, T.; Lochner, J. Web-based, virtual course units as a didactic concept for medical teaching. Med. Teach. 2004, 26, 336-342. [CrossRef]

21. Qi, S.; Yan, Y.; Li, R.; Hu, J. The impact of active versus passive use of 3D technology: A study of dental students at Wuhan University, China. J. Dent. Educ. 2013, 77, 1536-1542. [PubMed]

22. Reissmann, D.R.; Sierwald, I.; Berger, F.; Heydecke, G. A model of blended learning in a preclinical course in prosthetic dentistry. J. Dent. Educ. 2015, 79, 157-165. [PubMed]

23. Alves, L.S.; de Oliveira, R.S.; Nora, A.D.; Cuozzo Lemos, L.F.; Rodrigues, J.A.; Zenkner, J.E.A. Dental Students' Performance in Detecting In Vitro Occlusal Carious Lesions Using ICDAS with E-Learning and Digital Learning Strategies. J. Dent. Educ. 2018, 82, 1077-1083. [CrossRef] [PubMed] 
24. Luz, P.B.; Stringhini, C.H.; Otto, B.R.; Port, A.L.; Zaleski, V.; Oliveira, R.S.; Pereira, J.T.; Lussi, A.; Rodrigues, J.A. Performance of undergraduate dental students on ICDAS clinical caries detection after different learning strategies. Eur. J. Dent. Educ. 2015, 19, 235-241. [CrossRef] [PubMed]

25. Jackson, T.H.; Zhong, J.; Phillips, C.; Koroluk, L.D. Self-Directed Digital Learning: When Do Dental Students Study? J. Dent. Educ. 2018, 82, 373-378. [CrossRef]

26. Botelho, J.; Machado, V.; Proenca, L.; Rua, J.; Delgado, A.; Joao Mendes, J. Cloud-based collaboration and productivity tools to enhance self-perception and self-evaluation in senior dental students: A pilot study. Eur. J. Dent. Educ. 2019, 23, e53-e58. [CrossRef]

27. Boynton, J.R.; Johnson, L.A.; Nainar, S.M.; Hu, J.C. Portable digital video instruction in predoctoral education of child behavior management. J. Dent. Educ. 2007, 71, 545-549.

28. Weaver, J.M.; Lu, M.; McCloskey, K.L.; Herndon, E.S.; Tanaka, W. Digital multimedia instruction enhances teaching oral and maxillofacial suturing. J. Calif. Dent. Assoc. 2009, 37, 859-862.

29. Smith, W.; Rafeek, R.; Marchan, S.; Paryag, A. The use of video-clips as a teaching aide. Eur. J. Dent. Educ. 2012, 16, 91-96. [CrossRef]

30. Schittek Janda, M.; Mattheos, N.; Nattestad, A.; Wagner, A.; Nebel, D.; Farbom, C.; Le, D.H.; Attstrom, R. Simulation of patient encounters using a virtual patient in periodontology instruction of dental students: Design, usability, and learning effect in history-taking skills. Eur. J. Dent. Educ. 2004, 8, 111-119. [CrossRef]

31. Reynolds, P.A.; Harper, J.; Dunne, S.; Cox, M.; Myint, Y.K. Portable digital assistants (PDAs) in dentistry: Part II-Pilot study of PDA use in the dental clinic. Br. Dent. J. 2007, 202, 477-483. [CrossRef] [PubMed]

32. Pyorala, E.; Maenpaa, S.; Heinonen, L.; Folger, D.; Masalin, T.; Hervonen, H. The art of note taking with mobile devices in medical education. BMC Med. Educ. 2019, 19, 96. [CrossRef] [PubMed]

33. Mahrous, A.; Schneider, G.B.; Holloway, J.A.; Dawson, D.V. Enhancing Student Learning in Removable Partial Denture Design by Using Virtual Three-Dimensional Models Versus Traditional Two-Dimensional Drawings: A Comparative Study. J. Prosthodont. 2019, 28, 927-933. [CrossRef]

34. Callan, R.S.; Haywood, V.B.; Cooper, J.R.; Furness, A.R.; Looney, S.W. The Validity of Using E4D Compare's “\% Comparison" to Assess Crown Preparations in Preclinical Dental Education. J. Dent. Educ. 2015, 79, 1445-1451. [PubMed]

35. Esser, C.; Kerschbaum, T.; Winkelmann, V.; Krage, T.; Faber, F.J. A comparison of the visual and technical assessment of preparations made by dental students. Eur. J. Dent. Educ. 2006, 10, 157-161. [CrossRef]

36. Greany, T.J.; Yassin, A.; Lewis, K.C. Developing an All-Digital Workflow for Dental Skills Assessment: Part I, Visual Inspection Exhibits Low Precision and Accuracy. J. Dent. Educ. 2019, 83, 1304-1313. [CrossRef]

37. Hamil, L.M.; Mennito, A.S.; Renne, W.G.; Vuthiganon, J. Dental students' opinions of preparation assessment with E4D compare software versus traditional methods. J. Dent. Educ. 2014, 78, 1424-1431.

38. Kateeb, E.T.; Kamal, M.S.; Kadamani, A.M.; Abu Hantash, R.O.; Abu Arqoub, M.M. Utilising an innovative digital software to grade pre-clinical crown preparation exercise. Eur. J. Dent. Educ. 2017, 21, 220-227. [CrossRef]

39. Kozarovska, A.; Larsson, C. Implementation of a digital preparation validation tool in dental skills laboratory training. Eur. J. Dent. Educ. 2018, 22, 115-121. [CrossRef]

40. Kunkel, T.C.; Engelmeier, R.L.; Shah, N.H. A comparison of crown preparation grading via PrepCheck versus grading by dental school instructors. Int. J. Comput. Dent. 2018, 21, 305-311.

41. Liu, L.; Li, J.; Yuan, S.; Wang, T.; Chu, F.; Lu, X.; Hu, J.; Wang, C.; Yan, B.; Wang, L. Evaluating the effectiveness of a preclinical practice of tooth preparation using digital training system: A randomised controlled trial. Eur. J. Dent. Educ. 2018, 22, e679-e686. [CrossRef]

42. Mays, K.A.; Crisp, H.A.; Vos, P. Utilizing CAD/CAM to Measure Total Occlusal Convergence of Preclinical Dental Students' Crown Preparations. J. Dent. Educ. 2016, 80, 100-107.

43. Miyazono, S.; Shinozaki, Y.; Sato, H.; Isshi, K.; Yamashita, J. Use of Digital Technology to Improve Objective and Reliable Assessment in Dental Student Simulation Laboratories. J. Dent. Educ. 2019, 83, 1224-1232. [CrossRef] [PubMed]

44. Park, C.F.; Sheinbaum, J.M.; Tamada, Y.; Chandiramani, R.; Lian, L.; Lee, C.; Da Silva, J.; Ishikawa-Nagai, S. Dental Students' Perceptions of Digital Assessment Software for Preclinical Tooth Preparation Exercises. J. Dent. Educ. 2017, 81, 597-603. [CrossRef] [PubMed]

45. Gratton, D.G.; Kwon, S.R.; Blanchette, D.; Aquilino, S.A. Impact of Digital Tooth Preparation Evaluation Technology on Preclinical Dental Students' Technical and Self-Evaluation Skills. J. Dent. Educ. 2016, 80, 91-99. [PubMed] 
46. Gratton, D.G.; Kwon, S.R.; Blanchette, D.R.; Aquilino, S.A. Performance of two different digital evaluation systems used for assessing pre-clinical dental students' prosthodontic technical skills. Eur. J. Dent. Educ. 2017, 21, 252-260. [CrossRef] [PubMed]

47. Kwon, S.R.; Restrepo-Kennedy, N.; Dawson, D.V.; Hernandez, M.; Denehy, G.; Blanchette, D.; Gratton, D.G.; Aquilino, S.A.; Armstrong, S.R. Dental anatomy grading: Comparison between conventional visual and a novel digital assessment technique. J. Dent. Educ. 2014, 78, 1655-1662.

48. Garrett, P.H.; Faraone, K.L.; Patzelt, S.B.; Keaser, M.L. Comparison of Dental Students' Self-Directed, Faculty, and Software-Based Assessments of Dental Anatomy Wax-Ups: A Retrospective Study. J. Dent. Educ. 2015, $79,1437-1444$.

49. Mays, K.A.; Levine, E. Dental students' self-assessment of operative preparations using CAD/CAM: A preliminary analysis. J. Dent. Educ. 2014, 78, 1673-1680.

50. Sly, M.M.; Barros, J.A.; Streckfus, C.F.; Arriaga, D.M.; Patel, S.A. Grading Class I Preparations in Preclinical Dental Education: E4D Compare Software vs. the Traditional Standard. J. Dent. Educ. 2017, 81, 1457-1462. [CrossRef]

51. Lee, C.; Kobayashi, H.; Lee, S.R.; Ohyama, H. The Role of Digital 3D Scanned Models in Dental Students' Self-Assessments in Preclinical Operative Dentistry. J. Dent. Educ. 2018, 82, 399-405. [CrossRef] [PubMed]

52. Nagy, Z.A.; Simon, B.; Toth, Z.; Vag, J. Evaluating the efficiency of the Dental Teacher system as a digital preclinical teaching tool. Eur. J. Dent. Educ. 2018, 22, e619-e623. [CrossRef] [PubMed]

53. Wolgin, M.; Grabowski, S.; Elhadad, S.; Frank, W.; Kielbassa, A.M. Comparison of a prepCheck-supported self-assessment concept with conventional faculty supervision in a pre-clinical simulation environment. Eur. J. Dent. Educ. 2018, 22, e522-e529. [CrossRef] [PubMed]

54. Rees, J.S.; Jenkins, S.M.; James, T.; Dummer, P.M.; Bryant, S.; Hayes, S.J.; Oliver, S.; Stone, D.; Fenton, C. An initial evaluation of virtual reality simulation in teaching pre-clinical operative dentistry in a UK setting. Eur. J. Prosthodont. Restor. Dent. 2007, 15, 89-92.

55. Welk, A.; Maggio, M.P.; Simon, J.F.; Scarbecz, M.; Harrison, J.A.; Wicks, R.A.; Gilpatrick, R.O. Computer-assisted learning and simulation lab with 40 DentSim units. Int. J. Comput. Dent. 2008, 11, 17-40.

56. Gal, G.B.; Weiss, E.I.; Gafni, N.; Ziv, A. Preliminary assessment of faculty and student perception of a haptic virtual reality simulator for training dental manual dexterity. J. Dent. Educ. 2011, 75, 496-504.

57. Pohlenz, P.; Grobe, A.; Petersik, A.; von Sternberg, N.; Pflesser, B.; Pommert, A.; Hohne, K.H.; Tiede, U.; Springer, I.; Heiland, M. Virtual dental surgery as a new educational tool in dental school. J. Cranio-Maxillofac. Surg. 2010, 38, 560-564. [CrossRef]

58. Urbankova, A. Impact of computerized dental simulation training on preclinical operative dentistry examination scores. J. Dent. Educ. 2010, 74, 402-409.

59. Gottlieb, R.; Lanning, S.K.; Gunsolley, J.C.; Buchanan, J.A. Faculty impressions of dental students' performance with and without virtual reality simulation. J. Dent. Educ. 2011, 75, 1443-1451.

60. LeBlanc, V.R.; Urbankova, A.; Hadavi, F.; Lichtenthal, R.M. A preliminary study in using virtual reality to train dental students. J. Dent. Educ. 2004, 68, 378-383.

61. Murbay, S.; Neelakantan, P.; Chang, J.W.W.; Yeung, S. Evaluation of the introduction of a dental virtual simulator on the performance of undergraduate dental students in the pre-clinical operative dentistry course. Eur. J. Dent. Educ. 2019. [CrossRef] [PubMed]

62. Kikuchi, H.; Ikeda, M.; Araki, K. Evaluation of a virtual reality simulation system for porcelain fused to metal crown preparation at Tokyo Medical and Dental University. J. Dent. Educ. 2013, 77, 782-792.

63. Ben-Gal, G.; Weiss, E.I.; Gafni, N.; Ziv, A. Testing manual dexterity using a virtual reality simulator: Reliability and validity. Eur. J. Dent. Educ. 2013, 17, 138-142. [CrossRef] [PubMed]

64. Jasinevicius, T.R.; Landers, M.; Nelson, S.; Urbankova, A. An evaluation of two dental simulation systems: Virtual reality versus contemporary non-computer-assisted. J. Dent. Educ. 2004, 68, 1151-1162. [PubMed]

65. Quinn, F.; Keogh, P.; McDonald, A.; Hussey, D. A study comparing the effectiveness of conventional training and virtual reality simulation in the skills acquisition of junior dental students. Eur. J. Dent. Educ. 2003, 7, 164-169. [CrossRef]

66. Wang, D.; Zhao, S.; Li, T.; Zhang, Y.; Wang, X. Preliminary evaluation of a virtual reality dental simulation system on drilling operation. Biomed. Mater. Eng. 2015, 26 (Suppl. 1), S747-S756. [CrossRef] 
67. de Boer, I.R.; Lagerweij, M.D.; Wesselink, P.R.; Vervoorn, J.M. The Effect of Variations in Force Feedback in a Virtual Reality Environment on the Performance and Satisfaction of Dental Students. Simul. Healthc. 2019, 14, 169-174. [CrossRef]

68. Schwindling, F.S.; Deisenhofer, U.K.; Porsche, M.; Rammelsberg, P.; Kappel, S.; Stober, T. Establishing CAD/CAM in Preclinical Dental Education: Evaluation of a Hands-On Module. J. Dent. Educ. 2015, 79, 1215-1221.

69. Douglas, R.D.; Hopp, C.D.; Augustin, M.A. Dental students' preferences and performance in crown design: Conventional wax-added versus CAD. J. Dent. Educ. 2014, 78, 1663-1672.

70. Wegner, K.; Michel, K.; Seelbach, P.H.; Wostmann, B. A questionnaire on the use of digital denture impressions in a preclinical setting. Int. J. Comput. Dent. 2017, 20, 177-192.

71. Schott, T.C.; Arsalan, R.; Weimer, K. Students' perspectives on the use of digital versus conventional dental impression techniques in orthodontics. BMC Med. Educ. 2019, 19, 81. [CrossRef] [PubMed]

72. Zitzmann, N.U.; Kovaltschuk, I.; Lenherr, P.; Dedem, P.; Joda, T. Dental Students' Perceptions of Digital and Conventional Impression Techniques: A Randomized Controlled Trial. J. Dent. Educ. 2017, 81, 1227-1232. [CrossRef] [PubMed]

73. Lee, S.J.; Gallucci, G.O. Digital vs. conventional implant impressions: Efficiency outcomes. Clin. Oral Implant. Res. 2013, 24, 111-115. [CrossRef]

74. Marti, A.M.; Harris, B.T.; Metz, M.J.; Morton, D.; Scarfe, W.C.; Metz, C.J.; Lin, W.S. Comparison of digital scanning and polyvinyl siloxane impression techniques by dental students: Instructional efficiency and attitudes towards technology. Eur. J. Dent. Educ. 2017, 21, 200-205. [CrossRef] [PubMed]

75. Kattadiyil, M.T.; Jekki, R.; Goodacre, C.J.; Baba, N.Z. Comparison of treatment outcomes in digital and conventional complete removable dental prosthesis fabrications in a predoctoral setting. J. Prosthet. Dent. 2015, 114, 818-825. [CrossRef]

76. Murrell, M.; Marchini, L.; Blanchette, D.; Ashida, S. Intraoral Camera Use in a Dental School Clinic: Evaluations by Faculty, Students, and Patients. J. Dent. Educ. 2019, 83, 1339-1344. [CrossRef]

77. Soares, P.V.; de Almeida Milito, G.; Pereira, F.A.; Reis, B.R.; Soares, C.J.; de Sousa Menezes, M.; de Freitas Santos-Filho, P.C. Rapid prototyping and 3D-virtual models for operative dentistry education in Brazil. J. Dent. Educ. 2013, 77, 358-363.

78. Kroger, E.; Dekiff, M.; Dirksen, D. 3D printed simulation models based on real patient situations for hands-on practice. Eur. J. Dent. Educ. 2017, 21, e119-e125. [CrossRef]

79. Mileman, P.A.; van den Hout, W.B.; Sanderink, G.C. Randomized controlled trial of a computer-assisted learning program to improve caries detection from bitewing radiographs. Dentomaxillofac. Radiol. 2003, 32, 116-123. [CrossRef]

80. Minston, W.; Li, G.; Wennberg, R.; Nasstrom, K.; Shi, X.Q. Comparison of diagnostic performance on approximal caries detection among Swedish and Chinese senior dental students using analogue and digital radiographs. Swed. Dent. J. 2013, 37, 79-85.

81. Busanello, F.H.; da Silveira, P.F.; Liedke, G.S.; Arus, N.A.; Vizzotto, M.B.; Silveira, H.E.; Silveira, H.L. Evaluation of a digital learning object (DLO) to support the learning process in radiographic dental diagnosis. Eur. J. Dent. Educ. 2015, 19, 222-228. [CrossRef]

82. Kratz, R.J.; Nguyen, C.T.; Walton, J.N.; MacDonald, D. Dental Students' Interpretations of Digital Panoramic Radiographs on Completely Edentate Patients. J. Dent. Educ. 2018, 82, 313-321. [CrossRef]

83. Wenzel, A.; Kirkevang, L.L. Students' attitudes to digital radiography and measurement accuracy of two digital systems in connection with root canal treatment. Eur. J. Dent. Educ. 2004, 8, 167-171. [CrossRef]

84. Jathanna, V.R.; Jathanna, R.V.; Jathanna, R. The awareness and attitudes of students of one Indian dental school toward information technology and its use to improve patient care. Educ. Health (Abingdon) 2014, 27, 293-296. [CrossRef] [PubMed]

85. McCann, A.L.; Schneiderman, E.D.; Hinton, R.J. E-teaching and learning preferences of dental and dental hygiene students. J. Dent. Educ. 2010, 74, 65-78. [PubMed]

86. Ren, Q.; Wang, Y.; Zheng, Q.; Ye, L.; Zhou, X.D.; Zhang, L.L. Survey of student attitudes towards digital simulation technologies at a dental school in China. Eur. J. Dent. Educ. 2017, 21, 180-186. [CrossRef] [PubMed]

87. Roberts, B.S.; Roberts, E.P.; Reynolds, S.; Stein, A.F. Dental Students' Use of Student-Managed Google Docs and Other Technologies in Collaborative Learning. J. Dent. Educ. 2019, 83, 437-444. [CrossRef] [PubMed] 
88. Scarfe, W.C.; Potter, B.J.; Farman, A.G. Effects of instruction on the knowledge, attitudes and beliefs of dental students towards digital radiography. Dentomaxillofac. Radiol. 1996, 25, 103-108. [CrossRef]

89. Turkyilmaz, I.; Hariri, N.H.; Jahangiri, L. Student's Perception of the Impact of E-learning on Dental Education. J. Contemp. Dent. Pract. 2019, 20, 616-621. [CrossRef]

90. Chatham, C.; Spencer, M.H.; Wood, D.J.; Johnson, A. The introduction of digital dental technology into BDS curricula. Br. Dent. J. 2014, 217, 639-642. [CrossRef]

91. Brownstein, S.A.; Murad, A.; Hunt, R.J. Implementation of new technologies in U.S. dental school curricula. J. Dent. Educ. 2015, 79, 259-264.

92. Bhardwaj, A.; Nagandla, K.; Swe, K.M.; Abas, A.B. Academic Staff Perspectives Towards Adoption of E-learning at Melaka Manipal Medical College: Has E-learning Redefined our Teaching Model? Kathmandu Univ. Med. J. (KUMJ) 2015, 13, 12-18. [CrossRef]

93. Meng, L.; Hua, F.; Bian, Z. Coronavirus Disease 2019 (COVID-19): Emerging and Future Challenges for Dental and Oral Medicine. J. Dent. Res. 2020. [CrossRef]

94. Greany, T.J.; Yassin, A.; Lewis, K.C. Developing an All-Digital Workflow for Dental Skills Assessment: Part II, Surface Analysis, Benchmarking, and Grading. J. Dent. Educ. 2019, 83, 1314-1322. [CrossRef]

(C) 2020 by the authors. Licensee MDPI, Basel, Switzerland. This article is an open access article distributed under the terms and conditions of the Creative Commons Attribution (CC BY) license (http://creativecommons.org/licenses/by/4.0/). 